\title{
Direito à Educação da Pessoa com Deficiência Transformações Normativas e a Expansão da Inclusão no Brasil
}

\author{
Janine de Carvalho Ferreira Braga \\ Mestre em Direito Constitucional pela Universidade de \\ Fortaleza. Professora da Universidade de Fortaleza. Pes- \\ quisadora no grupo de pesquisa JET - Justiça em Trans- \\ formação (CNPq). janinebraga@unifor.br
}

\section{Gustavo Raposo Pereira Feitosa}

Doutor pela Unicamp. Professor titular do Programa de Pós-Graduação em Direito Constitucional da Universidade de Fortaleza e do Mestrado Profissional em Direito e Gestão de Conflitos. Professor-adjunto de Direito Processual Civil da FD-UFC. Líder do grupo de pesquisa JET - Justiça em Transformação (CNPq).gfeitosa@unifor.br

\section{Resumo}

No presente artigo aborda-se o direito à educação da pessoa com deficiência e sua proteção no Brasil, a partir de uma análise dos instrumentos normativos no plano internacional e no ordenamento jurídico brasileiro. Com base no contexto histórico da relação da sociedade com as pessoas com deficiência, mostra-se a evolução da abordagem dada à deficiência, desde sua fase primária de discriminação e segregação ao contemporâneo imperativo de inclusão social como princípio fundamental de garantia da dignidade humana e do direito à igualdade. Nesse contexto, faz-se o percurso constitucional brasileiro no que se refere ao direito à educação desde a Constituição Imperial até a Constituição Federal de 1988, assim como também da legislação infraconstitucional acerca do assunto. Por fim, tendo como ponto de partida a Declaração Universal dos Direitos Humanos, 
investigou-se a consolidação legislativa no plano internacional e brasileiro do direito à educação de pessoas com deficiência, na perspectiva inclusiva e no âmbito do sistema educacional geral, pela Convenção Internacional Sobre os Direitos da Pessoa com Deficiência, aprovada pelo Brasil com status de Emenda Constitucional, e, internamente, pelo Estatuto da Pessoa com Deficiência. Instituído pela Lei $n^{\circ} 13.146 / 2015$, o Estatuto da Pessoa com Deficiência sistematiza a regulamentação acerca da garantia dos direitos das pessoas com deficiência, contudo sua análise centra-se no aspecto educacional e em suas relações com as premissas da Convenção Internacional sobre os Direitos da Pessoa com Deficiência.

Palavras-chave: Direito à educação. Pessoa com deficiência. Convenção Internacional Sobre os Direitos da Pessoa com Deficiência.

\title{
The Right to Education of Person with Disabilities: legal transformation and the expansion of the inclusion in Brazil
}

\begin{abstract}
This article discusses the Right do Education of person with disabilities and their legal protection in Brazil. The study is based on a legislative analysis at international level and, more specifically, the Brazilian legal system. Analysing the historical context of the relation between society and people with disabilities, it is possible to realize the evolution of the approach given to disability people since its primary phase of discrimination and segregation to contemporary imperative of social inclusion as a fundamental principle of ensuring human dignity and right to equality. In this context, it was analyzed the right to education from the Imperial Constitution to the Federal Constitution of 1988, as well as the infra-constitutional legislation about it. Finally, from the Universal Declaration of Human Rights, it was realized the legislative consolidation in the international and brazilian right to education of persons with disabilities in the inclusive perspective and within the general education system, the first international treaty of human rights in the XXI century, the International Convention on the rights of Persons with Disabilities, adopted by Brazil with constitutional amendment status, and, internally, the Statute of Person with Disabilities (Law № 13.146/2015). The Statute systematizes regulations on the guarantee of the rights of persons with disabilities, including education, and it establishes the State's obligations to its effectiveness, adopting consistent with the premises of the International Convention on the rights of Persons with disabilities, the social conception of disability.
\end{abstract}

Keywords: Right to education. Persons with disabilities. International Convention on the Rights of Disabled People.

\section{Sumário}

1 Introdução. 2 Direito à Educação da Pessoa com Deficiência no Plano Internacional. 2.1 Direito à educação e a Convenção Internacional sobre os Direitos das Pessoas com Deficiência. 3 Direito à Educação de Pessoas com Deficiência no Brasil. 3.1 Percurso constitucional do direito à educação. 3.2 Direito à Educação Inclusiva no Brasil. 4 Conclusões. 5 Referências. 


\section{INTRODUÇÃO}

A educação é direito de todos. É dever do Estado. É dever da família. Visa ao pleno desenvolvimento da pessoa. Prepara para o exercício da cidadania. Capacita para o trabalho. Essa é a essência do artigo 205 da Constituição da República Federativa do Brasil de 1988. Não se pode negar a relevância da educação em qualquer sociedade, o que demonstra a importância do estudo acerca dos preceitos constitucionais de garantia desse direito, pressuposto para a consolidação da dignidade humana na realidade brasileira.

Nesse contexto insere-se o direito à educação das pessoas com deficiência. Compreendendo-se a educação como elemento indissociável ao pleno desenvolvimento da personalidade humana e requisito indispensável à concretização da própria cidadania, mostra-se imperativa a garantia de acesso à educação e o tratamento isonômico a todas as pessoas indistintamente. Às pessoas com deficiência, em decorrência de sua própria condição específica, são impostos maiores obstáculos, de forma que, no percurso da inclusão, a garantia de isonomia por si só não a realiza efetivamente.

Neste artigo objetiva-se traçar os contornos do direito à educação das pessoas com deficiência, no plano internacional, a partir da investigação sobre as principais convenções internacionais relativas ao tema e, no âmbito interno, com o estudo dos textos constitucionais, além das principais normas infraconstitucionais inerentes à educação inclusiva, fazendo-se uma correlação entre o processo legislativo brasileiro de inclusão social e o movimento internacional acerca do assunto.

Considerando as premissas normativas protetivas da pessoa com deficiência no Brasil, pretende-se apresentar, ainda, os dados disponibilizados pelo Instituto Nacional de Estudos e Pesquisas Educacionais Anísio Teixeira - Inep - no percurso do Censo da Educação Básica desde 1994, a 
fim de verificar a participação da pessoa com deficiência na escola, especificamente analisando-se sua inserção conforme os parâmetros observados na evolução do tratamento do assunto na legislação brasileira.

\section{DIREITO À EDUCAÇÃO DA PESSOA COM DEFICIÊNCIA NO PLANO INTERNACIONAL}

O reconhecimento da educação como instrumento político ocorre somente a partir do século 16 , quando emerge a ideia de uma educação nacional, muito embora ainda houvesse uma resistência à universalização do ensino, em razão do temor de que essa universalização provocasse desvio das profissões e a criação de deslocamentos sociais (MONTEIRO, 1999).

Monteiro (1999) faz uma trajetória histórica da inserção da educação no rol de direitos do homem, observando que a Declaração dos Direitos do Homem, em 1789, foi um marco para essa evolução, servindo de inspiração para as normas constitucionais que lhe sucediam. A partir dessa inspiração a Constituição Francesa, de 1791, trouxe referência à educação de crianças abandonadas, assim como uma "instrução" comum a todos os cidadãos e gratuita, no que se refere ao ensino mínimo para todos os homens.

Segundo Mazzotta (2011), apenas a partir do século $18^{1}$ começa-se a falar na educação voltada a pessoas com deficiência, ainda não integrada, muito menos inclusiva, mas marcada pela institucionalização da educação

${ }^{1}$ Bueno (1993, p. 58) esclarece que "a maior parte dos escritos que, de alguma forma, se dedica à história da educação especial, considera o século XVI como a época em que se iniciou a educação dos deficientes, através da educação da criança surda. Antes disso, segundo esses autores, os deficientes eram encaminhados aos asilos, onde permaneciam segregados e sem atenção, ou então, viviam como mendigos, sobrevivendo às custas da caridade pública. Esse período é considerado como uma época de precursores, por se restringir somente à criança surda, por não se desenvolver através da instituição 
de pessoas com deficiência, com a criação das primeiras escolas públicas para seu atendimento. Na verdade, a oferta era muito mais restrita a abrigo, terapia, assistência, sem efetivamente ter conotação educacional propriamente dita.

Essas escolas surgiram na França, na segunda metade do século 18, em meio à agitação liberal e aos anseios por mudanças políticas. A primeira delas foi o Instituto Nacional de Surdos-Mudos criado em 1760, e, em seguida, o Instituto dos Jovens Cegos $^{2}$ (fundado em 1784). Após alguns anos, enquanto o Instituto Nacional de Surdos-Mudos adquiriu o estatuto de Instituto Nacional (muito embora não deixasse de ser um internato), o Instituto dos Jovens Cegos notadamente se transformou em asilo com trabalho obrigatório (BUENO, 1993, p. 69).

Foi a partir da experiência das instituições de ensino para pessoas com deficiência na França que a maior parte dos países passou a criar estabelecimentos similares. No Brasil, na segunda metade do século 19, foram criados o Imperial Instituto dos Meninos Cegos, hoje intitulado Instituto

escola (como ocorrerá a partir do século XVIII) e por envolver um número reduzido de deficientes”. Da mesma forma, a educação de pessoas cegas também teve início antes do século 18. Conforme Bueno (1993, p. 61), há registros nos primeiros anos da sociedade burguesa, que alguns cegos receberam educação formal, ainda que diante de escassez de recursos didático-pedagógicos, chegando a um bom nível de aprendizagem. Nos dois casos, educação de surdos e cegos, tratava-se de um "privilégio" daquelas pessoas com deficiência que pertenciam às classes dominantes, esclarecendo que "a par daqueles milhares de cegos infortunados, pertencentes ao povo miúdo, que viviam à própria sorte ou internados em asilos, alguns poucos, nesse mesmo período, conseguiram se destacar, não porque tivessem recebido atendimento especializado, mas porque a limitação imposta por sua deficiência não impedia nem o contato social, nem a aprendizagem de conhecimentos, com exceção da escrita, porque ambos poderiam se basear exclusivamente na linguagem oral. É claro que pertenciam às elites (...)”.

${ }^{2}$ Foi no Instituto de Cegos de Paris que Louis Braille, um jovem de 15 anos cego em razão de um acidente doméstico, desenvolveu um sistema de escrita por meio de pontos em relevo. Seu sistema somente foi reconhecido como meio eficaz e adequado à substituição da linguagem escrita até então ensinada aos cegos oficialmente em 1854 (dois anos após a morte de Louis Braille), viabilizando um grande avanço na escolarização de pessoas cegas, que precisavam desenvolver a leitura por meio do tato. 
Benjamim Constant, e o Instituto dos Surdos-Mudos, atualmente conhecido como o Instituto Nacional de Educação de Surdos (Ines) (SILVA, 1986, p. 285-287).

A Constituição Francesa de $1848^{3}$ foi a primeira a reconhecer a educação efetivamente como direito, assim como estabeleceu, em seu preâmbulo, ser dever do poder público seu provimento, mas com propósito notadamente distinto dos anseios sociais originários de sua instituição.

A convocação de assembleia constituinte francesa naquele ano deu-se por um governo provisório, em meio ao descontentamento da classe operária urbana diante dos excessos do monarca Luís Felipe de Orléans (instalado no trono em 1830), assim como à fome no campo diante do fracasso da colheita dos anos de 1846-1847. A revolta popular de Paris, em fevereiro de 1848, visava, além da derrubada do rei, à reinstauração da República, com os mesmos anseios revolucionários de 1792-1793 (COMPARATO, 1999).

As forças revolucionárias não tiveram tempo para promoção de uma campanha de esclarecimento do eleitorado, o que acabou por resultar na composição de uma Assembleia Constituinte formada em sua maioria absoluta por deputados do centro (conhecidos como "republicanos moderados”, somando 500 de um total de 880 deputados), com participação de cerca de cem deputados da esquerda e os demais monarquistas. Entre calorosos debates e grandes conflitos de interesses, a Constituição Francesa de 1848 estabeleceu-se como uma “obra de compromisso”, de um lado entre os conservadores (com ênfase nos valores da família, proprie-

\footnotetext{
3 "Art. 13. A Constituição garante aos cidadãos a liberdade de trabalho e de indústria. A sociedade favorece e encoraja o desenvolvimento do trabalho, pelo ensino primário gratuito, a educação profissional, a igualdade nas relações entre patrão e operário, as instituições de previdência e de crédito, as instituições agrícolas, as associações voluntárias e o estabelecimento, pelo Estado, os Departamentos e os Municípios, de obras públicas capazes de empregar os braços desocupados; ela fornece assistência às crianças abandonadas, aos doentes e idosos sem recursos e que não podem ser socorridos por suas famílias" (FRANÇA, 1848, apud COMPARATO, 1999, p. 172).
} 
dade e ordem pública), e do outro, os militantes do progresso e da civilização. Inobstante todas as contradições que surgiam a partir de então, não se pode deixar de reconhecer sua contribuição, diante da instituição de deveres sociais do Estado (embora limitados à edição de leis orgânicas, e com ênfase no mercado de trabalho), para a criação do que se conheceria posteriormente, no século 20, como Estado do Bem-Estar Social. É nesse contexto que a inserção do direito à educação na Constituição Francesa de 1848 se dá muito mais para a formação do mercado de trabalho do que propriamente para a formação do cidadão (COMPARATO, 1999).

A partir da análise das Constituições que passaram a vigorar entre as duas grandes guerras mundiais, Monteiro (1999) identifica, no que se refere à educação, características básicas comuns, tais como o privilégio a uma autoridade de fiscalização dos Estados, aos seus poderes de direção e a uma influência sobre a instrução e suas diversas formas. O autor destaca que, de fato, via-se um direito à instrução e não à educação, de forma que a recorrente garantia constitucional de direito à instrução pública não representava o direito do homem à educação.

A Constituição Alemã de Weimar de 1919, nascida com o propósito de reconstrução política do Estado após a grande guerra de 1914-1918, sedimentou o entendimento da educação escolar como dever fundamental do Estado e direito natural dos pais. Neste modelo, a educação figurava como uma obrigação escolar geral sob o controle do Estado. Verificou-se grande ênfase no ensino cívico e no desenvolvimento do espírito da nacionalidade alemã, mas com atenção ao respeito quanto aos sentimentos daqueles que tinham pensamentos divergentes. O objetivo da educação sedimentada nessa Constituição alemã era de aquisição de "qualidades físicas, intelectuais e sociais” (MONTEIRO, 1999).

Comparato (1999) credita às disposições inerentes à educação pública e ao direito do trabalho da Constituição Alemã de 1919 o protagonismo para a organização das bases da democracia social. No que se refere ao direito à educação, o texto constitucional consolidou os valores 
sociais que se estabelecem em razão da evolução durante o século 19, de forma que competiria ao Estado o dever de seu provimento, estabelecendo que a educação fundamental teria duração de oito anos e que a educação complementar atenderia o educando até os seus 18 anos (artigo 145), sendo gratuitos tanto o ensino quanto o material escolar em ambos os níveis de ensino. Trouxe grande inovação ao possibilitar a adaptação do ensino escolar à cultura e religião das famílias (artigo 146), assim como estabeleceu subsídios públicos aos pais de educandos aptos a cursar o Ensino Médio e Superior (parte final do artigo 146).

Não obstantes tais inovações normativas, somente a partir das Constituições surgidas no pós-guerra que se constata avanço significativo no campo do direito à educação, sobretudo após a Declaração Universal dos Direitos Humanos, em 1948. A criação da Organização das Nações Unidas - ONU - e o advento da Declaração Universal dos Direitos Humanos representam o marco histórico nesse processo, ao positivar a dignidade humana como preceito fundamental.

A aprovação da Declaração Universal dos Direitos Humanos deu-se em 10 de dezembro de 1948, por 48 Estados, entre eles o Brasil, na Assembleia Geral das Nações Unidas, servindo, a partir de então, de inspiração no processo de crescimento de diversas nações para uma nova percepção de seus ordenamentos jurídicos e no realinhamento do sistema de valores adotados por eles, numa perspectiva de concretude dos pilares fundamentais da igualdade entre os homens e da dignidade da pessoa humana. Bobbio (1992) compreende o advento da Declaração de 1948 como o início de uma fase na qual a afirmação dos direitos é universal e positiva.

É nesse sentido o disposto no seu artigo $1^{0}$, ao estabelecer que “Todas as pessoas nascem livres e iguais em dignidade e em direitos. São dotadas de razão e de consciência e devem agir em relação umas às outras com espírito de fraternidade”. A Declaração Universal tanto estabelece o conjunto de direitos consagrados pelas revoluções burguesas (direitos de liberdade, ou direitos civis e políticos) quanto os estende a sujeitos 
que estavam deles excluídos (proibição da escravidão, reconhecimento dos direitos das mulheres, defesa dos direitos dos estrangeiros, etc.) e abre espaço para o desenvolvimento posterior dos direitos sociais (direitos de igualdade, ou direitos econômicos e sociais) e do cristianismo social (direitos de solidariedade).

A Declaração Universal dos Direitos Humanos, portanto, projeta no âmbito normativo internacional a garantia de igualdade de direitos ao homem, independente de sexo, raça, religião, idade, ou qualquer espécie de condições físicas, sensoriais ou intelectuais.

Bobbio ressalta (1992, p. 28):

Somente depois da Declaração Universal é que podemos ter a certeza histórica de que a humanidade - toda a humanidade - partilha alguns valores comuns; e, podemos, finalmente, crer na universalidade dos valores, no único sentido em que tal crença é historicamente legítima, ou seja, no sentido em que universal significa não algo dado objetivamente, mas algo subjetivamente acolhido pelo universo dos homens.

O reconhecimento universal da essencialidade da igualdade entre os homens, pressuposto da dignidade humana, promove a própria sobrevivência da humanidade, premissa que se consolidou, formalmente, no âmbito internacional com a Declaração Universal de 1948, com as trágicas lições decorrentes "da mais desumanizadora guerra de toda a História”, diante das consequências devastadoras do espírito de superioridade de uma raça, uma classe social, uma cultura ou uma religião, sobre as demais (COMPARATO,1999, p. 228).

Com relação ao direito à educação, a Declaração de 1948 assim estabelece em seu preâmbulo:

A ASSEMBLÉIA GERAL proclama a presente DECLARAÇÃO UNIVERSAL DOS DIRETOS HUMANOS como o ideal comum a ser atingido por todos os povos e todas as nações, com o objetivo de que cada indivíduo e cada órgão da sociedade, tendo sempre em mente esta 
Declaração, se esforce, através do ensino e da educação, por promover o respeito a esses direitos e liberdades, e, pela adoção de medidas progressivas de caráter nacional e internacional, por assegurar o seu reconhecimento e a sua observância universal e efetiva, tanto entre os povos dos próprios Estados-Membros, quanto entre os povos dos territórios sob sua jurisdição. (grifos nossos).

A educação foi reconhecida, e declarada, como instrumento para consecução dos objetivos da Declaração, com o fim de promoção do respeito aos direitos e liberdades por ela declarados. E continua, em seu artigo 26, estabelecendo que "todo ser humano tem direito à instrução", que será gratuita, pelo menos nos graus elementares e fundamentais. Muito embora o termo utilizado tenha sido “instrução”, a própria Declaração trata de estabelecer, nesse mesmo artigo, que "a instrução será orientada no sentido do pleno desenvolvimento da personalidade humana e do fortalecimento do respeito pelos direitos humanos e pelas liberdades fundamentais" e que “a instrução promoverá compreensão, a tolerância e a amizade entre todas as nações e grupos raciais ou religiosos, e coadjuvará as atividades das Nações Unidas em prol da manutenção da paz”.

Verifica-se, desde então, um conjunto de determinações internacionais que, de alguma forma, tratam a questão da educação e da educação inclusiva. Realizada em Jomtien, na Tailândia, em 1990, a Conferência Mundial de Educação para Todos teve relevante papel na indicação de uma nova e ousada orientação no que se refere à educação. Aprovada na Conferência, a Declaração Mundial sobre a Educação para Todos tem como premissa, que permeia todo o seu texto desde o preâmbulo, a satisfação das necessidades básicas de aprendizagem, e estabelece em seu artigo $1^{\circ}$, item I, que "cada pessoa - criança, jovem ou adulto - deve estar em condições de aproveitar as oportunidades educativas voltadas para satisfazer suas necessidades básicas de aprendizagem”.

$\mathrm{E}$, continua, no que se refere às pessoas com deficiência, em seu artigo $3^{\circ}$, itens I e $\mathrm{V}$, dispondo que: 
1. A educação básica deve ser proporcionada a todas as crianças, jovens e adultos. Para tanto, é necessário universalizá-la e melhorar sua qualidade, bem como tomar medidas efetivas para reduzir as desigualdades. [...]

5. As necessidades básicas de aprendizagem das pessoas portadoras de deficiências requerem atenção especial. É preciso tomar medidas que garantam a igualdade de acesso à educação aos portadores de todo e qualquer tipo de deficiência, como parte integrante do sistema educativo.

Em 1994, na Conferência Mundial sobre Necessidades Especiais em Salamanca, na Espanha, surgiu a Declaração de Salamanca sobre Princípios, Política e Prática em Educação Especial, que se apresenta como um dos documentos internacionais mais relevantes no que se refere à educação inclusiva. Segundo seus princípios orientadores, as escolas deveriam acomodar todas as crianças independentemente de suas condições físicas, intelectuais, sociais, emocionais, linguísticas, etc.

A Declaração de Salamanca possui papel-chave na criação de políticas públicas e ações para assegurar o direito à educação das pessoas com deficiência, reafirmando o compromisso dos 88 governos e 25 organizações internacionais ali representadas com a Educação para Todos, "reconhecendo a necessidade e urgência do providenciamento de educação para as crianças, jovens e adultos com necessidades educacionais especiais dentro do sistema regular de ensino”, declarando que:

Aqueles com necessidades educacionais especiais devem ter acesso à escola regular, que deveria acomodá-los dentro de uma Pedagogia centrada na criança, capaz de satisfazer a tais necessidades (ORGANIZAÇÃO..., 1994) 
Assim, a Declaração de Salamanca marca definitivamente a premissa de inclusão como meio eficaz de promoção da educação de pessoas com deficiência, de forma a garantir o combate a atitudes discriminatórias e que as coloque à margem do sistema regular de ensino. E, para tanto, reconhece que

[...] escolas regulares que possuam tal orientação inclusiva constituem os meios mais eficazes de combater atitudes discriminatórias criando-se comunidades acolhedoras, construindo uma sociedade inclusiva e alcançando educação para todos; além disso, tais escolas provêem uma educação efetiva à maioria das crianças e aprimoram a eficiência e, em última instância, o custo da eficácia de todo o sistema educacional (ORGANIZAÇÃO..., 1994).

Muito embora não trate especificamente do direito à educação, a Convenção Interamericana para a Eliminação de todas as Formas de Discriminação da Pessoa Portadora de Deficiência, de 1999, revela extrema importância para o estudo das garantias e direitos fundamentais dessa parcela da sociedade. Ratificada e promulgada pelo Brasil por meio do Decreto $\mathrm{n}^{0} 3.956 / 2001$, a Convenção proíbe qualquer distinção que acarrete exclusão ou restrição de acesso a direitos fundamentais e é nesse sentido que se insere a educação.

\subsection{Direito à educação e a Convenção Internacional sobre os Direitos das Pessoas com Deficiência}

A partir, portanto, do paradigma social baseado no respeito à diferença e numa atitude inclusiva quanto às pessoas com deficiência, surge em $2006^{4}$ o primeiro tratado internacional sobre direitos humanos do

${ }^{4}$ A Convenção Internacional sobre os Direitos das Pessoas com Deficiência foi elaborada ao longo de quatro anos, contando com a participação de 192 países-membros da Organização das Nações Unidas - ONU - e centenas de representantes da sociedade civil de todo o mundo. O texto final deste tratado internacional foi aprovado em 13 de dezembro de 2006, 
século 21, a Convenção Internacional sobre os Direitos das Pessoas com Deficiência, em que se definem direitos e obrigações de todos os seres humanos. Ocorre aí um verdadeiro marco da educação inclusiva no âmbito internacional, tendo em vista a consolidação de uma visão atual sobre o assunto e a clareza de seus preceitos para a efetividade dessa inclusão.

O Brasil ratificou com brevidade a Convenção, tendo sido um dos primeiros países a assiná-la, em 30 de março de 2007. A Convenção foi aprovada pelo Senado Federal por meio do Decreto Legislativo n⿳0 186, de 9 de julho de 2008, e ratificada por intermédio do Decreto $\mathrm{n}^{\circ} 6.949$, de 25 de agosto de 2009 .

No seu artigo $1^{\circ}$, a Convenção declara ter por objetivo a promoção, proteção e segurança para o integral gozo de todos os direitos humanos e liberdades fundamentais pelas pessoas com deficiência e promoção ao respeito da sua dignidade.

A autonomia, a liberdade de escolha, a não discriminação, a igualdade de oportunidades, e, principalmente, o respeito pela diferença e aceitação da deficiência como parte da diversidade humana, tudo isso em um contexto de absoluta inclusão social, dispostos no artigo $3^{05}$ da Convenção, evidenciam a própria expressão do princípio constitucional que garante a dignidade da pessoa humana.

em sessão solene da ONU, firmado pelo Brasil e por mais 85 nações, em 30 de março de 2007. Atualmente, 150 países já ratificaram a Convenção. Para a presidente do Comitê sobre os Direitos das Pessoas com Deficiência (CRPD), Maria Soledad Cisternas Reyes, "a ratificação do $150^{\circ}$ país é uma prova do compromisso da comunidade internacional para promover e proteger os direitos humanos das pessoas com deficiência” (NAÇÕES..., 2014).

${ }^{5}$ Artigo $3^{\circ}$. Os princípios da presente Convenção são: a) O respeito pela dignidade inerente, a autonomia individual, inclusive a liberdade de fazer as próprias escolhas, e a independência das pessoas; b) A não-discriminação; c) A plena e efetiva participação e inclusão na sociedade; d) $\mathrm{O}$ respeito pela diferença e pela aceitação das pessoas com deficiência como parte da diversidade humana e da humanidade; e) A igualdade de oportunidades; f) A acessibilidade; g) A igualdade entre o homem e a mulher; h) O respeito pelo desenvolvimento das capacidades das crianças com deficiência e pelo direito das crianças com deficiência de preservar sua identidade. 
$\mathrm{O}$ princípio da isonomia encontra-se previsto nos artigos $5^{\circ}$ e 12 da Convenção, em que há o reconhecimento por parte dos Estados signatários de que todas as pessoas com deficiência são iguais perante a lei, estando assegurados, sem discriminação, sua proteção e benefícios, devendo-se adotar medidas que proíbam qualquer prática discriminatória. O próprio texto do artigo $5^{\circ}$, item IV, da norma internacional, esclarece que os tratamentos específicos que forem necessários para acelerar ou alcançar a efetiva igualdade das pessoas com deficiência "não serão considerados discriminatórios”, em uma clara demonstração de que se busca a efetivação da igualdade de fato.

Especificamente no que respeita ao direito à educação, o artigo 24 disciplina o reconhecimento por parte dos Estados-partes do direito das pessoas com deficiência à educação, na medida em que fica assegurado o sistema educacional inclusivo em todos os níveis, a fim de efetivar esse direito sem discriminação e com base na igualdade de oportunidades. Para tanto, o artigo estabelece as obrigações dos Estados para a garantia desse direito, destacando-se que as pessoas com deficiência, de qualquer idade, não sejam excluídas do sistema educacional geral, em nenhum nível, sob alegação de deficiência, assim como que recebam o apoio necessário, no âmbito do sistema educacional geral, com vistas a facilitar sua efetiva educação.

A efetivação desses preceitos fica sob a responsabilidade de cada Estado-parte (artigo $4^{\circ}$ ), que se comprometem, entre outras ações, a adotar as medidas necessárias, quer legislativas, administrativas ou de qualquer outra natureza, para o cumprimento dos direitos reconhecidos na Convenção. Caberá, ainda, aos Estados-partes, apresentar relatório sobre as medidas adotadas no cumprimento de suas obrigações decorrentes da Convenção e sobre o progresso alcançado nesse aspecto, dentro do 
período de dois anos após o início de sua vigência naquele Estado-parte (artigo 35), o que será acompanhado pelo Comitê sobre os Direitos das Pessoas com Deficiência, instituído nos termos do artigo 34 da Convenção.

O Comitê será responsável pela análise, apresentação de sugestões e recomendações gerais que julgar pertinentes aos respectivos Estados-partes, cabendo-lhe, ainda, prestar o suporte necessário junto a agências, fundos e programas especializados das Nações Unidas e a outras organizações competentes, da maneira que julgar apropriada, a partir do envio dos relatórios dos Estados-partes que "contenham demandas ou indicações de necessidade de consultoria ou de assistência técnica, acompanhados de eventuais observações e sugestões do Comitê em relação às referidas demandas ou indicações, a fim de que possam ser consideradas" (artigo 36).

O Comitê das Nações Unidas sobre os Direitos das Pessoas com Deficiência realizou nos dias 25 e 26 de agosto de 2015 uma avaliação sobre os progressos e desafios do Brasil para a instituição da Convenção Internacional sobre os Direitos das Pessoas com Deficiência. Essa avaliação foi feita por meio de um diálogo interativo entre os especialistas do Comitê e uma delegação do Estado brasileiro, em Genebra (Suíça), conduzido pela Presidente do Comitê, Maria Soledad Cisternas Reyes (NAÇÕES..., 2015; UNITED NATIONS, 2015).

As observações finais sobre o relatório inicial (UNITED NATIONS, 2015) do Brasil quanto à instalação da Convenção Internacional sobre os Direitos das Pessoas com Deficiência foi divulgado em 4 de setembro de 2015, tendo sido o país parabenizado pela atribuição à “Convenção equivalência de uma emenda constitucional, pela criação de comissões e conselhos sobre direitos das pessoas com deficiência nas diversas esferas, bem como pela adoção de várias medidas para melhorar a acessibilidade para pessoas com deficiência”. O Comitê também destacou preocupações, dentre elas, e principalmente, "falta de adoção de um modelo de direitos 
humanos frente à deficiência”, assim como destacou a necessidade de adoção de um mecanismo para sistematização da legislação, políticas e programas intersetoriais para responder às múltiplas formas de discriminação contra as pessoas com deficiência. Identificou a necessidade de melhorias nas políticas de educação, saúde, trabalho e emprego, participação na vida cultural, recreação, lazer e esporte, para a plena garantia dos direitos das pessoas com deficiência.

Por fim, destacou a falta de dados específicos em diversas áreas sobre essa população. As recomendações do Comitê devem servir de base para a definição de políticas públicas e para a execução de ações pelo governo brasileiro, que deverá submeter novo relatório em relação às medidas tomadas para cumprimento dessas recomendações até $1^{\circ}$ de setembro de 2022.

\section{DIREITO À EDUCAÇÃO DE PESSOAS COM DEFICIÊNCIA NO BRASIL}

O direito à educação figura como direito social, inserido no rol dos direitos fundamentais, nos termos do que dispõe o artigo $6^{\circ}$, da Constituição Federal Brasileira, sendo, inclusive, protegido em razão dos limites ao poder reformador. Entende-se a educação como elemento indissociável ao pleno desenvolvimento da personalidade humana e requisito indispensável à dignidade da pessoa humana e à concretização da própria cidadania. Consequentemente, educação é pressuposto necessário à evolução do Estado Democrático de Direito, considerando que a qualificação para o trabalho e a capacidade crítica dos indivíduos mostram-se indispensáveis à realização dos fundamentos e objetivos da República Federativa do Brasil, nos termos dos artigos $1^{\circ}$ e $3^{\circ}$ da Constituição Federal Brasileira (BRASIL, 1988). 
Para a análise do direito à educação de pessoas com deficiência no Brasil, inicialmente será traçado o percurso constitucional do direito à educação, para, em seguida, abordar o estudo da legislação infraconstitucional brasileira acerca do tema, assim como a inserção brasileira no contexto internacional de garantia desse direito. Ressalte-se aqui o reconhecimento de que a dimensão normativa representa apenas um aspecto dos problemas relacionados à expansão da educação em geral e, em particular, da educação para a pessoa com deficiência. Não obstante, por razões metodológicas, o presente estudo ateve-se à análise dos instrumentos normativos e suas transformações até o cenário atual.

\subsection{Percurso constitucional do direito à educação}

Ao se perceber a educação como elemento indissociável do desenvolvimento social de um povo, relaciona-se o tratamento que a legislação brasileira deu à matéria. Muito embora esse direito tenha sido previsto em Constituições passadas, sua abordagem ainda se dava, na maior parte das vezes, de forma tímida e restrita.

A maior ou menor presença de disposições acerca da educação nos textos constitucionais ao longo da História do Brasil demonstra, em boa medida, a relevância dada ao assunto em cada um desses momentos políticos. O contexto histórico de cada Constituição repercutia de forma clara nas mudanças ou manutenções macroestruturais inerentes às questões relativas à educação (VIEIRA, 2007).

A análise dos textos constitucionais viabiliza uma reflexão acerca de uma parte da evolução da política educacional brasileira, de forma que se possa também estabelecer o cenário em que foram discutidas as medidas inerentes à educação escolar e o quanto desse contexto interfere na sua concepção e abrangência. 
A primeira Constituição Brasileira foi promulgada em 1824, no primeiro momento político subsequente à Independência do Brasil. Muito embora a Assembleia Constituinte tenha iniciado seus trabalhos em maio de 1823, foi dissolvida pelo então Imperador Dom Pedro I, por divergência dos deputados brasileiros. Dom Pedro I convocou um Conselho de Estado para reelaborar o projeto originalmente apresentado e orientar a elaboração de um texto para manutenção de seu poder pessoal, estabelecendo um quarto poder, o Poder Moderador, exercido pelo Imperador e que lhe possibilitava ampla liberdade de intervenção na vida política do país (IGLESIAS, 1985).

A Constituição do Império de $1824^{6}$ garantia a educação na forma de instrução primária gratuita a todos os cidadãos, assim definidos no seu artigo $6^{0}{ }^{7}$ que excluía os escravos. Inobstante a menção à educação no texto constitucional, mesmo sem a indicação de políticas de promoção da educação que demonstrassem ruptura com a dinâmica colonial, constata-se o caráter reducionista da garantia de instrução básica, na medida em que grande parte da população brasileira era composta por escravos. A definição restritiva de cidadania por si já era elemento de restrição da titularidade do direito à educação, além das condições precárias de ensino

${ }^{6}$ Artigo 179. "A inviolabilidade dos Direitos Civis, e Políticos dos Cidadãos Brazileiros, que tem por base a liberdade, a segurança individual, e a propriedade, é garantida pela Constituição do Imperio, pela maneira seguinte. (...) XXXII. A Instrucção primaria, e gratuita a todos os Cidadãos; XXXIII. Colégios e universidades, onde serão ensinados os elementos das ciências, belas letras e artes” (sic).

${ }^{7}$ Artigo 6‥ "São Cidadãos Brazileiros: I. Os que no Brazil tiverem nascido, quer sejam ingenuos, ou libertos, ainda que o pai seja estrangeiro, uma vez que este não resida por serviço de sua Nação; II. Os filhos de pai Brazileiro, e os illegitimos de mãi Brazileira, nascidos em paiz estrangeiro, que vierem estabelecer domicilio no Imperio; III. Os filhos de pai Brazileiro, que estivesse em paiz estrangeiro em serviço do Imperio, embora elles não venham estabelecer domicilio no Brazil; IV. Todos os nascidos em Portugal, e suas Possessões, que sendo já residentes no Brazil na época, em que se proclamou a Independencia nas Provincias, onde habitavam, adheriram á esta expressa, ou tacitamente pela continuação da sua residência; V. Os estrangeiros naturalisados, qualquer que seja a sua Religião. A Lei determinará as qualidades precisas, para se obter Carta de naturalização" (sic). 
à época. Conforme Oliveira (1995, p. 68), “o analfabetismo era a condição de instrução da maioria da população e o poder público não desenvolveu esforços para transformar efetivamente a educação em Política pública”.

Nesse sentido, Vieira (2007, p. 10-11) traz relatos de deputados em momentos de debates acerca da educação na Constituinte de 1823 que retratavam a precariedade da educação em suas regiões, diante da ausência de escolas, escassez de professores e prática de salários miseráveis. Esse panorama retrata, em grande medida, o cenário da educação brasileira no período imperial.

Em 15 de outubro de 1827 foi publicada a Lei que estabeleceu a determinação de criação de "escolas de primeiras letras em todas as cidades, vilas e lugares mais populosos do Império”. Essa Lei pode ser considerada a primeira Lei de Diretrizes e Bases da Educação no Brasil, tendo tratado em seus 17 artigos de questões diversas da educação (a exemplo da definição do método de ensino a ser adotado - ensino mútuo, ${ }^{8}$ castigos, formas de provisão de professores, seus salários, determinações sobre os prédios escolares, a criação de escola para meninas e os conteúdos que lhes deviam ser ensinados). A lei silenciou acerca da gratuidade do ensino e da natureza pública da instrução. O panorama normativo no tocante ao direito à educação permanece sem alterações importantes ao logo de todo o Império.

\footnotetext{
${ }^{8}$ Nesse método, a responsabilidade do ensino é dividida entre o professor e os monitores alunos com maior experiência e conhecimento que os demais, de forma que se consegue, simultaneamente e com apenas um professor, instruir centenas de alunos, inclusive de níveis escolares distintos. Foi uma etapa na história da instrução brasileira que viabilizou a difusão da instrução elementar aos trabalhadores, por meio da necessária racionalização do ato pedagógico, que se caracterizava naqueles moldes como rápida, de baixo custo, disciplinar, com usos de poucos professores e vários alunos monitores (BASTOS, 1997).
} 
A Proclamação da República, em 1889, muito embora seja marcada por expectativas e projetos contraditórios, ${ }^{9}$ traz consigo anseios de reforma também no campo da educação. Estava-se diante de uma população em grande parte analfabeta, constituída por uma parcela considerável de escravos libertos e imigrantes que vinham para o país em busca de trabalho. Havia a necessidade de preparação daquela população para assumir, de fato, seu papel na sociedade, o que evidencia a importância da instrução pública no país naquele momento, o que se apresentava como um grande desafio, tendo em vista o pequeno número de instituições de ensino e a escassez de pessoas habilitadas a assumir a docência. Ao mesmo tempo, a presença marcante da “cultura da escravidão”, com a rejeição da integração dos negros e o temor de que os imigrantes se afastassem do trabalho nas fazendas ou se envolvessem em movimentos políticos, bloqueava toda e qualquer pretensão de expansão do ensino no país.

A Constituição de 1891 surgiu, no que se refere à educação, sob o contexto da Reforma Benjamin Constant, ${ }^{10}$ com a aprovação dos Decretos no 981/90 e 1.075/90 (Regulamentos de Instrução Primária e secundária do Distrito Federal e do Ginásio Nacional, respectivamente) e do Decreto nº 1.232-G/91 (Regulamento do Conselho de Instrução Superior), que já estabeleciam, pela primeira vez, o estudo seriado, em que os alunos cur-

\footnotetext{
${ }_{9}^{9} \mathrm{O}$ Exército estava à frente do movimento e seu líder era o marechal Deodoro da Fonseca, que tanto era monarquista como amigo do Imperador (VIEIRA, 2007, p. 12).

${ }^{10}$ Segundo Cartolano (1994, p. 129), Benjamin Constant "acreditava que só pela educação um povo poderia construir a sua cidadania”, razão pela qual se dedicou à realização de mudanças educacionais nas escolas militar, normal e da instrução primária e secundária. À frente do Ministério da Instrução Pública, Correios e Telégrafos, o primeiro dedicado à educação, Benjamin Constant foi determinante na efetivação da instrução popular no país, tendo como princípios a liberdade, gratuidade e laicidade do ensino.
} 
savam gradualmente cada série, inicialmente cumprindo as etapas do $1^{0}$ grau e, posteriormente, do $2^{\circ}$ grau. Após a realização do exame final, com sua aprovação ficavam aptos a seguir no Ensino Superior. ${ }^{11}$

A primeira Constituição Republicana Brasileira (e que perdurou por cerca de quatro décadas), no que se refere ao direito à educação, estabele$\mathrm{ceu}^{12}$ que cabia ao Congresso, mas não privativamente, promover o desenvolvimento das letras, artes e ciências, além de estabelecer a criação de instituições de ensino superior e secundário ${ }^{13}$ nos Estados e, nesse último caso, também no Distrito Federal. Nesse ponto, a Constituição de 1891 inicia uma tendência que se consolidou na política educacional brasileira, considerando o incentivo à criação de Instituições de Ensino Superior e da Educação Básica (Ensinos Fundamental e Médio) por parte dos governos locais. Nessa Constituição, em seu artigo $72, \S 6^{\circ}$, ficou estabelecido que o ensino ministrado nos estabelecimentos públicos seria leigo, o que marca a separação entre Estado e Igreja.

${ }^{11}$ Deve-se esclarecer que a instrução pública naquele momento de reforma tinha como objetivo principal formar cidadãos para a realidade social da época. Mezzari (2001, p. 89-90) esclarece que "outro objetivo da Reforma foi o de fundamentar a educação na ciência, em detrimento da tradição clássica. A predominância literária, de acordo com a ordenação positivista e liberal, foi substituída pela científica, embora, segundo, José Veríssimo, Benjamin Constant não demonstrasse conhecer suficientemente as concepções de educação de Augusto Comte, pois incluía já na escola de $1^{\circ}$ grau a aritmética, a geometria prática e, na de $2^{\circ}$ grau que se iniciava aos 13 anos, além destas, a trigonometria, as ciências físicas e naturais".

${ }^{12}$ Art 35 - "Incumbe, outrossim, ao Congresso, mas não privativamente: (...); $2^{\underline{0}}$ ) animar no Pais o desenvolvimento das letras, artes e ciências, (...); $3^{\circ}$ ) criar instituições de ensino superior e secundário nos Estados; $4^{\circ}$ ) prover a instrução secundária no Distrito Federal”.

${ }^{13} \mathrm{O}$ ensino secundário mencionado na Constituição Federal de 1891, assim como nos demais textos constitucionais e nas Convenções Internacionais que tratam da educação e serão mencionadas no presente trabalho, corresponde ao atual Ensino Médio, disposto nos artigos $4^{\circ}$ e 35, da Lei nº 9.394/1996 (Lei de Diretrizes e Bases da Educação Nacional). 
Vieira (2007, p. 14) afirma que, nesse cenário, a educação ainda não apontava para a promoção de atividades de pesquisa, muito embora destaque que a Reforma Benjamin Constant já revelava maior preocupação com a formação científica no país.

Apesar de descentralizador no que se refere à educação, o texto constitucional de 1891 não apresentava o mesmo avanço quanto à ampliação de direitos políticos, com a manutenção da proibição do voto por analfabetos e mendigos (artigo 70, $\S 1^{\circ}$ ). Cury (2001, p. 191-192) relaciona essa condição à reserva do direito social à educação para as elites, o que, por consequência, deixa considerável parcela da população impedida de participação política democrática, posto que impedida de votar em razão do analfabetismo. Nesse sentido, a Constituição de 1891 discrimina essa parcela da população por duas vias, seja por estabelecer a regra do sufrágio restrito, seja por silenciar em relação à gratuidade e obrigatoriedade da educação primária (CURY, 2001, p. 191).

Constrói-se um sistema sofisticado de segregação e negação do acesso à vida política em que a falta de oferta de instituições de Ensino Fundamental implica não apenas a negação do direito à educação, mas o bloqueio do direito ao voto. A descentralização fortalece ainda o poder dos grupos políticos locais sobre esta importante dimensão da vida dos cidadãos na medida em que vincula o maior controle político sobre as pessoas mais pobres à preservação do analfabetismo. O modelo apresenta, assim, uma característica perversa, pois cria um estímulo político à negação do acesso à educação aos mais pobres.

Em plena efervescência política, com a ascensão de Getúlio Vargas ao poder em 1930 (assumindo o governo provisório, para, em seguida, ser eleito presidente da República pelo Congresso em 1934), inicia-se um amplo processo de mudanças, nos campos político, econômico e social. A 
Constituição de $1934^{14}$ inovou ao incluir todo um capítulo dedicado à matéria da educação e da cultura, estabelecendo uma divisão de competências entre os entes federativos, ${ }^{15}$ garantindo a liberdade de cátedra, previsão de isenção de tributos para estabelecimentos educacionais, criação da obrigação de se manter fundos de educação (oferecimento gratuito, aos alunos necessitados, de "material escolar, bolsas de estudo, assistência alimentar, dentária e médica”), gratuidade de ensino primário ${ }^{16} \mathrm{e}$ "tendências à gratuidade do ensino educativo ulterior ao primário, a fim de torná-lo mais acessível”, favorecimento ao ensino religioso (de frequência facultativa e conforme a religião do aluno e sua família) e à escola privada (isenção de impostos àquelas instituições particulares consideradas idôneas).

Com a Constituição de 1937, imposta pelas forças ditatoriais do poder, "mudam-se as circunstâncias políticas, mudam-se os mecanismos legais para fazer valer novas regras de convivência social” (VIEIRA, 2002, p. 176). É ampliada a competência da União para, além de traçar as diretrizes, "fixar as bases e determinar os quadros da educação nacional, traçando as diretrizes a que deve obedecer a formação física, intelectual e moral da infância e da juventude" (artigo 15, IX).

\footnotetext{
${ }^{14}$ Constituição da República dos Estados Unidos do Brasil, de 16 de julho de 1934, artigos 148-158.

${ }^{15}$ Os Estados e Distrito Federal continuam responsáveis pela organização e manutenção dos sistemas educativos (artigo 151), mas cabe à União estabelecer as diretrizes da educação nacional (artigo $5^{\circ}$, XIX).

${ }^{16}$ Considerando o momento histórico de cada legislação, serão mencionados os ensinos primário e secundário em alguns dispositivos (inclusive na Convenção Internacional sobre os Direitos das Pessoas com Deficiência). Atualmente, por força do artigo 21 da Lei $\mathrm{n}^{0}$ 9.394/96, Lei de Diretrizes e Bases da Educação Nacional, a educação escolar brasileira é composta pela Educação Básica (formada pela Educação Infantil, Ensino Fundamental e Ensino Médio) e pela Educação Superior. O ensino primário corresponde ao Ensino Fundamental e o ensino secundário corresponde ao Ensino Médio.
} 
A Constituição de $1937{ }^{17}$ manteve um capítulo dedicado à educação, incluindo a garantia de acesso ao ensino em todos os seus níveis à infância e à juventude, tendo sido dada prioridade ao ensino pré-vocacional e profissional. A livre-iniciativa mantida no texto constitucional deixa claro o caráter subsidiário do Estado, que passa a exercer uma função compensatória (artigo 129). Foi mantida a obrigatoriedade e gratuidade do ensino primário, muito embora tenha sido prevista uma contribuição para aqueles que não declarassem escassez de recursos financeiros.

Nesse sentido, Vieira (2002, p. 177) observa que o texto constitucional consolida a ideia de que a educação pública é destinada àqueles que não podem pagar, portanto, à parcela mais pobre da população; destaca que a política educacional dedica-se prioritariamente ao ensino profissional e classifica como "retrocesso" a ampliação das possibilidades dada ao ensino religioso, que, embora ainda facultativo, passa a poder ser incluído como matéria do curso ordinário das escolas primárias, normais e secundárias.

As concepções sobre educação contidas na Era Vargas expressam um contexto de transformações econômicas e políticas tanto no Brasil como no cenário internacional. Prevalece a orientação para uma formação profissionalizante, guiada pela expectativa de crescimento da indústria e da maior demanda de força de trabalho nos centros urbanos. Sobressai ainda o temor de que a falta de controles centrais e a presença de escolas mantidas por comunidades de imigrantes gerassem riscos ao país e a um projeto de afirmação da nacionalidade brasileira.

Após a queda de Getúlio Vargas em 1945 e a eleição de Eurico Gaspar Dutra, promulgou-se uma nova Constituição em 1946 que, no campo da educação, realizou tão somente um aperfeiçoamento do que havia sido estabelecido em 1934, sem mudanças significativas. Na sua

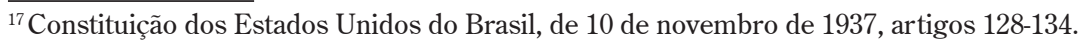


vigência foi publicada a Lei n⿳0 4.024, de 20 de dezembro de 1961 (primeira Lei de Diretrizes e Bases da Educação Nacional - LDB brasileira), que estabeleceu a educação como direito de todos, assegurando a obrigatoriedade do ensino primário, tendo acrescentado que o ensino oficial ulterior ao primário assim também seria para aqueles que comprovassem falta ou insuficiência de recursos. Com a LDB de 1961, os diferentes níveis e modalidades de ensino passam a ser reunidos em um único texto normativo e, pela primeira vez, trata-se da educação de pessoas com deficiência (artigos 88 e 89).

Na Constituição Federal de 1967, elaborada na vigência da ditadura militar de 1964, não se verificaram alterações substanciais na matéria destinada à educação, tendo o assunto sido tratada no capítulo intitulado "Da Família, da Educação e da Cultura” (artigos 167-172). O desenho adotado revela sintonia com as características autoritárias e excessivamente conservadoras do regime político.

Nesse período, a educação de pessoas com deficiência foi mencionada pela primeira vez em um texto normativo na Emenda Constitucional $\mathrm{n}^{\mathrm{0}} 1$, de 1969, mas ocorreu tão somente para indicar que caberia à lei especial dispor sobre a educação de “excepcionais”, tanto que inclui a matéria em artigo destinado à família e sua proteção pelo Estado. ${ }^{18}$

Foi a Emenda Constitucional $\mathrm{n}^{\mathrm{0}}$ 12, de 1978, que de forma pioneira, ainda que incipiente, ampliou reconhecimento dos direitos das pessoas com deficiência, com a proteção ao direito à educação em seu artigo único, que dispõe:

Art. único. É assegurado aos deficientes a melhoria de sua condição social e econômica especialmente mediante:

18 “Art. 175. A família é constituída pelo casamento e terá direito à proteção dos Podêres Públicos. $\S 1^{\circ} \mathrm{O}$ casamento é indissolúvel. (...) $\S 4^{\circ}$ Lei especial disporá sôbre a assistência à maternidade, à infância e à adolescência e sôbre a educação de excepcionais" (sic). 
I - educação especial e gratuita;

II - assistência, reabilitação e reinserção na vida econômica e social do País;

III - proibição de discriminação, inclusive quanto à admissão ao trabalho ou ao serviço público e a salários;

IV - possibilidade de acesso a edifícios e logradouros públicos.

A grande transformação normativa, contudo, nasce no ambiente da redemocratização. Trata-se de uma verdadeira renovação da perspectiva sobre o significado da educação e do tratamento dado aos direitos da pessoa com deficiência. A Constituição Federal de 1988, ao disciplinar os direitos sociais em seu artigo $6^{\circ}$, incluiu a educação no rol desses direitos, e disciplinou a matéria nos artigos 205 a 214, estabelecendo que:

Art. 205. A educação, direito de todos e dever do Estado e da família, será promovida e incentivada com a colaboração da sociedade, visando ao pleno desenvolvimento da pessoa, seu preparo para o exercício da cidadania e sua qualificação para o trabalho.

Além da relevância da inclusão do direito à educação no rol dos direitos sociais, assim considerado um direito fundamental, o constituinte inovou positivamente ao estabelecer os princípios do ensino e ao criar artigos específicos que tratam da autonomia universitária e do plano nacional de educação.

A efetividade do direito à educação é condição imprescindível para a consecução dos objetivos fundamentais da República na forma prevista no artigo $3^{\circ}$. Sem a garantia da educação, não há como pensar a construção de uma sociedade justa, livre e solidária, a garantia do desenvolvimento nacional, a erradicação da pobreza e da marginalização, com a redução das desigualdades sociais e regionais e a promoção do bem de todos, sem preconceitos de origem, raça, sexo, cor, idade e quaisquer outras formas de discriminação. 
Sobre estes pressupostos, o constituinte originário estabelece as obrigações do Estado em busca da concretização e efetividade do direito à educação, conforme dispõe no artigo 208, III, da Constituição Federal Brasileira de 1988, mediante a garantia de "atendimento educacional especializado aos portadores de deficiência, preferencialmente na rede regular de ensino" ${ }^{19}$

A norma constitucional representa muito mais do que o disposto em seus artigos que se referem diretamente à pessoa com deficiência podem estabelecer. No novo ambiente constitucional e democrático pós1988 consolida-se "supraprincípio” da dignidade da pessoa humana, em toda a sua abrangência. É nessa perspectiva que a garantia fundamental da inviolabilidade do direito à igualdade vincula-se de maneira indissociável à realização da dignidade humana para permear não somente a legislação infraconstitucional vindoura a partir de sua promulgação, mas essencialmente as políticas públicas concebidas e estabelecidas a partir de então.

\footnotetext{
${ }^{19}$ Além do tratamento dado ao direito à educação da pessoa com deficiência, o legislador constituinte incluiu especial atenção às pessoas com deficiência em diversos outros aspectos (artigo $7^{\circ}$, XXXI - proteção ao trabalhador; artigo 23 - competência comum da União, Estados e municípios para cuidar de sua saúde e assistência pública, proteção e garantia; art. 37, VIII - reserva de percentual dos cargos e empregos públicos; artigo $40, \S 4^{\circ}$, I e artigo 201, $\S 1^{\circ}$ - requisitos e critérios diferenciados para a concessão de aposentadoria; artigo 203, IV e V - dentre os objetivos da assistência social estão a) habilitação e reabilitação das pessoas com deficiência e a promoção de sua integração à vida comunitária, e b) a garantia de um salário mínimo de benefício mensal à pessoa com deficiência que comprove não possuir meios de prover à própria manutenção ou de tê-la provida por sua família, conforme dispuser a lei.; artigo 227 , $\S 1^{\circ}$, II - criação de programas de prevenção e atendimento especializado para as pessoas com deficiência física, sensorial ou mental, bem como de integração social do adolescente e do jovem com deficiência, mediante o treinamento para o trabalho e a convivência, e a facilitação do acesso aos bens e serviços coletivos, com a eliminação de obstáculos arquitetônicos e de todas as formas de discriminação e artigo 244 - dever de adaptação dos logradouros, dos edifícios de uso público e dos veículos de transporte coletivo atualmente existentes a fim de garantir acesso adequado às pessoas com deficiência).
} 
Sob essa premissa constitucional, todo o ordenamento jurídico infraconstitucional brasileiro deveria atender aos preceitos de igualdade na sua dimensão mais efetiva, em que o tratamento desigual justifica-se para que as pessoas tenham condição de igualdade. Tais condicionantes mostram-se essenciais para a compreensão dos pressupostos do direito à educação inclusiva no Brasil, bem como das suas relações com a garantia desse direito no plano internacional.

\subsection{Direito à Educação Inclusiva no Brasil}

Inserido no rol dos direitos sociais, na Constituição Federal Brasileira o direito à educação configura-se como condição necessária, ainda que não suficiente, para o exercício de todos os demais direitos, sejam eles civis, políticos, sociais, econômicos ou de qualquer outra natureza. $\mathrm{O}$ texto constitucional (e de diversas convenções internacionais) ${ }^{20}$ consagra o caráter de fundamentalidade do direito à educação por estar este intrinsecamente relacionado aos princípios fundamentais da República Federativa do Brasil, e, de forma especial, ao princípio da dignidade humana.

No Brasil, especificamente no que se refere à educação inclusiva, o tratamento legal dado à questão é recente. A Lei 4.024/1961,21 primeira Lei de Diretrizes e Bases para a Educação Brasileira, em seu Título X, enquadrou a "educação de excepcionais" (sic) no sistema geral de educação, visando à integração desses alunos na comunidade e prevendo apoio finan-

\footnotetext{
${ }^{20}$ Artigo 26 da Declaração Universal dos Direitos Humanos (1948) e artigos 13 e 14 do Pacto Internacional sobre os direitos Econômicos, Sociais e Culturais (1948).

${ }^{21}$ TÍTULO X - Da Educação de Excepcionais

${ }^{A}$ rt. 88. A educação de excepcionais deve, no que for possível, enquadrar-se no sistema geral de educação, a fim de integrá-los na comunidade (Revogado pela Lei n⿳0 9.394, de 1996).

${ }^{A}$ rt. 89. Toda iniciativa privada considerada eficiente pelos conselhos estaduais de educação, e relativa à educação de excepcionais, receberá dos poderes públicos tratamento especial mediante bolsas de estudo, empréstimos e subvenções.
} 
ceiro às entidades privadas dedicadas a essa especialidade. A abordagem, como se vê, tinha uma perspectiva assistencialista, mas foi o início de um processo de integração dos alunos com deficiência na escola.

Um ano após a promulgação da Constituição Federal Brasileira de 1988, que não somente tratou com amplitude o direito à educação, mas o fez também em relação às pessoas com deficiência já condizente com a orientação legislativa internacional de promoção da inclusão na rede regular de ensino, foi sancionada a Lei n⿳o 7.853/1989, que

[...] dispõe sobre o apoio às pessoas portadoras de deficiência, sua integração social, sobre a Coordenadoria Nacional para Integração da Pessoa Portadora de Deficiência - Corde, institui a tutela jurisdicional de interesses coletivos ou difusos dessas pessoas, disciplina a atuação do Ministério Público, define crimes, e dá outras providências.

Reafirmando o direito à educação da pessoa com deficiência, na Lei $\mathrm{n}^{\mathrm{0}} 7.853 / 1989$ fica estabelecido que compete ao poder público e seus órgãos assegurar às pessoas com deficiência o pleno exercício de seus direitos básicos, dentre eles o direito à educação, objetivando propiciar seu bem-estar pessoal, social e econômico. Para tanto, estabelece, em seu artigo $2^{\underline{0}}$, § único, I, 'a’, na área da educação, a inclusão no sistema educacional, da Educação Especial como modalidade educativa em todos os níveis e modalidades de ensino, muito embora estabeleça que ocorrerá "com currículos, etapas e exigências de diplomação próprios".

Esta lei reforça, ainda, os direitos da criança e do adolescente com deficiência à educação ao estabelecer, em seu artigo $8^{\circ}$, como crime, punível com reclusão de 1 (um) a 4 (quatro) anos, e multa, "recusar, suspender, procrastinar, cancelar ou fazer cessar, sem justa causa, a inscrição de aluno em estabelecimento de ensino de qualquer curso ou grau, público ou privado, por motivos derivados da deficiência que porta”. 
O legislador infraconstitucional inovou, logo após a promulgação da Constituição Federal, com a criação de um sistema educacional inclusivo, muito embora ainda se observasse uma conotação de integração, de educação especial diferenciada daquela ofertada no sistema regular de ensino. Considerando o contexto histórico, esse foi um importante passo para a consolidação futura do direito à educação inclusiva no país.

Em 1990 publicou-se o Estatuto da Criança e do Adolescente, Lei $\mathrm{n}^{\circ}$ 8.060, que prioriza a criança e o adolescente, estabelecendo direitos e obrigações do Estado para sua proteção. No que se refere ao direito à educação das crianças e adolescentes com deficiência, o Estatuto estabelece, em seu artigo 53, que "a criança e o adolescente têm direito à educação, visando ao pleno desenvolvimento de sua pessoa, preparo para o exercício da cidadania e qualificação para o trabalho”. Para tanto, em seus incisos, assegura, entre outros direitos, a igualdade de condições para o acesso e permanência na escola.

Quanto aos deveres do Estado, está assegurado no artigo 54 “o atendimento educacional especializado aos portadores de deficiência, preferencialmente na rede regular de ensino, dentre outras garantias”.

O Censo Demográfico de $1991^{22}$ foi o primeiro a fazer levantamento acerca da população de pessoas com deficiência, por força de lei. ${ }^{23}$ A pesquisa acerca da população de pessoas com deficiência, naquele momento,

\footnotetext{
${ }^{22}$ Muito embora a realização do Censo seja decenal e a edição anterior tenha ocorrido em 1980, não houve Censo em 1990 por questões inerentes à autorização de contratação de pessoal. Como a autorização ocorreu apenas em julho de 1990, não haveria tempo hábil para as demais etapas do processo de recenseamento. Por essa razão optou-se pela realização do Censo no ano seguinte. Foi o X Recenseamento Geral do Brasil e teve início em $1^{\circ}$ de setembro de 1991, tendo compreendido apenas o Censo Demográfico (INSTITUTO..., 2000).

${ }^{23}$ Desde os levantamentos da época do Império até o censo demográfico de 1920, o escopo do levantamento eram as deficiências sensoriais (cegos e surdos-mudos, conforme termos utilizados à época). A partir do censo de 1940 as informações sobre cada uma das deficiências passam a abranger a natureza dessas deficiências (motivo de doença,
} 
era subdividida em física ou mental, ${ }^{24}$ portanto um modelo ainda centrado nas características corporais. O resultado revelou que o Brasil tinha, àquela época, 146.815 .795 habitantes, com 1.667 .785 pessoas com pelo menos uma das modalidades de deficiência, portanto 1,14\% da população declarou ter algum tipo de deficiência.

Com a publicação da Lei nº 9.394, Lei de Diretrizes e Bases da Educação - LDB - em 1996, a educação brasileira passa a ter uma legislação específica nascida sob a orientação da Constituição Federal de 1988 e, portanto, regulamentadora dos direitos declarados constitucionalmente.

A LDB incorpora os ditames constitucionais, especificamente no que se refere às pessoas com deficiência, no intuito de garantia do direito à educação. Ao criar um capítulo específico para a “educação especial”, no entanto, tende a garantir a realização desse direito, mas sob a perspectiva de criação de um subsistema à parte, muito embora permeado do princípio de respeito às diferenças.

Em seu artigo 58, ${ }^{25}$ em sua redação original, a LDB definiu educação especial como "a modalidade de educação escolar, oferecida preferencialmente na rede regular de ensino, para educandos portadores de necessidades especiais”. Muito embora avance na aproximação entre a

acidente, nascença ou não declararam a causa) (LENZI, 2012, p. 14). O artigo 17, da Lei n⿳o 7.853/1989, estabelece que "serão incluídas no censo demográfico de 1990, e nos subseqüentes, questões concernentes à problemática da pessoa portadora de deficiência, objetivando o conhecimento atualizado do número de pessoas portadoras de deficiência no País” (sic), de forma que, em 1991, um dos levantamentos feitos pelo Censo dizia respeito à população de pessoas com deficiência, assim entendidas deficiências físicas ou mentais em geral.

${ }^{24} \mathrm{O}$ Censo de 1991 foi realizado por meio de um questionário de amostra, que englobava $10 \%$ dos domicílios, nos municípios com mais de 15.000 habitantes, e $20 \%$ nos demais, o que representava cerca de 4 milhões de questionários (Instituto Brasileiro de Geografia e Estatística - IBGE. Sínteses históricas. Históricos dos Censos. Censos demográficos, 2016).

${ }^{25} \mathrm{O}$ texto final do artigo 58 da LDB foi alterado por força da Lei ${ }^{\circ} 12.796$, de 4 de abril de 2013, substituindo-se a referência a "pessoas portadoras de necessidade especiais" por "educandos com deficiência, transtornos globais do desenvolvimento e altas habilidades ou superdotação". 
educação especial e a rede regular de ensino, a LDB ainda se utiliza de medidas específicas e serviços especializados (classes, escolas ou serviços propriamente ditos) como solução nas hipóteses de não "integração" das pessoas com deficiências às classes comuns de ensino regular $\left(\S \S 1^{\circ} \mathrm{e} 2^{\circ}\right.$, artigo 58).

Em 19 de dezembro de 2000 foi publicada a Lei n⿳ํㅡㄹ 10.098, que "estabelece normas gerais e critérios básicos para a promoção da acessibilidade das pessoas portadoras de deficiência ou com mobilidade reduzida”, com escopo de supressão das barreiras e obstáculos nas vias e espaços públicos, no mobiliário urbano, na construção e reforma de edifícios e nos meios de transporte e de comunicação. No que se refere à educação, igualmente restringe seu tratamento a questões de barreiras arquitetônicas, definindo em seu artigo 17 que o poder público estabelecerá

[...] mecanismos e alternativas técnicas que tornem acessíveis os sistemas de comunicação e sinalização às pessoas portadoras de deficiência sensorial e com dificuldade de comunicação, para garantir-lhes o direito de acesso à informação, à comunicação, ao trabalho, à educação, ao transporte, à cultura, ao esporte e ao lazer.

O avanço dessa perspectiva com a percepção do efetivo conceito de inclusão surge no Brasil com a Resolução CNE/CEB n. 2/2001, do Conselho Nacional de Educação - CNE (BRASIL, 2001b). Em atendimento ao disposto no Capítulo V da LDB, que trata da Educação Especial, a Resolução estabelece as Diretrizes Nacionais para a Educação Especial na Educação Básica, sendo documento fundamental das proposições nacionais voltadas à educação inclusiva.

Em seu artigo $2^{\circ}$, a referida Resolução finalmente regulamenta a inclusão educacional ao estabelecer que "os sistemas de ensino devem matricular todos os alunos, cabendo às escolas organizar-se para o aten- 
dimento aos educandos com necessidades educacionais especiais, assegurando as condições necessárias para uma educação de qualidade para todos”.

A proposta de mudança no tratamento da educação de pessoas com deficiência permeia o discurso político à época e traz traços de efetiva compreensão da necessidade de mudança de concepção em relação à inclusão e adaptações necessárias para tanto. Por força da Resolução CNE/CEB n. 2/2001, são instituídas as Diretrizes Nacionais para a Educação Especial na Educação Básica (BRASIL, 2001a), que "vêm representar ao mesmo tempo um avanço na perspectiva da universalização do ensino e um marco fundacional quanto à atenção à diversidade na educação brasileira”.

Nas palavras de Paulo Renato Souza, ministro da Educação à época da instituição das Diretrizes Nacionais para a Educação Especial Básica, observa-se a mudança de paradigma na concepção da educação inclusiva no Brasil, de forma que

[...] em vez de se pensar no aluno como a origem de um problema, exigindo-se dele um ajustamento a padrões de normalidade para aprender com os demais, coloca-se para os sistemas de ensino e para as escolas o desafio de construir coletivamente as condições para atender bem à diversidade de seus alunos (BRASIL, 2001a, p. 6).

Reconhecendo que as transformações para a construção da inclusão na área educacional permeiam ações inerentes aos âmbitos político, técnico-científico, pedagógico e administrativo, na apresentação das Diretrizes Nacionais para a Educação Especial na Educação Básica (BRASIL, 2001a, p. 6), Paulo Renato Souza reconhece que:

[...] participar do processo educativo juntamente com os demais alunos - contando com os serviços e recursos especiais necessários - é um direito dos alunos que apresentam necessidades educacionais espe- 
ciais. Empreender as transformações necessárias para que essa educação inclusiva se torne realidade nas escolas brasileiras é uma tarefa de todos.

A universalização da matrícula de todos os alunos, não se fazendo qualquer distinção em relação àqueles com deficiência, atende aos ditames de educação inclusiva, de forma que caberá às escolas organizarem-se para o atendimento a alunos com necessidades especiais, mas com objetivo de prestação adequada do serviço educacional e não prestação diferenciada desse serviço. Nas Diretrizes Nacionais para a Educação Especial na Educação Básica (BRASIL, 2001a, p. 20) reconhece-se que a inclusão educacional é parte integrante do processo de construção de uma sociedade inclusiva, fundamental para o desenvolvimento e a manutenção da democracia, estabelecendo-se, portanto, a necessidade de políticas públicas de caráter emancipatório:

Certamente, cada aluno vai requerer diferentes estratégias pedagógicas, que lhes possibilitem o acesso à herança cultural, ao conhecimento socialmente construído e à vida produtiva, condições essenciais para a inclusão social e o pleno exercício da cidadania. Entretanto, devemos conceber essas estratégias não como medidas compensatórias e pontuais, e sim como parte de um projeto educativo e social de caráter emancipatório e global.

A educação especial, portanto, é reconhecida como modalidade de educação escolar e não mais como categoria distinta de educação. Está inserida, via de regra, na prestação de serviços educacionais comuns, assim estabelecendo os artigos $3^{\circ}$ e $7^{\circ}$ da Resolução $\operatorname{CNE} n^{\circ}$ 2/2001:

Art. $3^{\circ}$ Por educação especial, modalidade da educação escolar, entende-se um processo educacional definido por uma proposta pedagógica que assegure recursos e serviços educacionais especiais, organizados institucionalmente para apoiar, complementar, suplementar e, em alguns casos, substituir os serviços educacionais comuns, de modo 
a garantir a educação escolar e promover o desenvolvimento das potencialidades dos educandos que apresentam necessidades educacionais especiais, em todas as etapas e modalidades da educação básica.

(...)

Art. $7^{\circ} \mathrm{O}$ atendimento aos alunos com necessidades educacionais especiais deve ser realizado em classes comuns do ensino regular, em qualquer etapa ou modalidade da Educação Básica.

Nesse sentido, o artigo $8^{\circ}$ da referida Resolução CNE n⿳ำ 2/2001 fixa os parâmetros para previsão e provimento desse atendimento às pessoas com deficiência na organização das salas comuns, dentre os quais se destacam a capacitação de professores, a distribuição dos alunos com necessidades especiais pelas várias classes do ano escolar em que se inserirem, flexibilizações e adaptações curriculares, serviços de apoio pedagógico especializado, projetos de sustentabilidade da educação inclusiva, temporalidade flexível do ano letivo e atividades que favoreçam o aprofundamento e enriquecimento de aspectos curriculares aos alunos com altas habilidades/superdotação.

Garcia (2005, p. 345) esclarece a importância dessa Resolução, notadamente no amadurecimento acerca da abrangência do conceito de inclusão:

Percebe-se, neste documento, uma apreensão da educação inclusiva como algo específico da educação especial, ou seja, a educação torna-se "inclusiva" uma vez que incorpora a educação especial formalmente na educação básica. Tal apropriação tem como uma de suas consequiências a ampliação em termos do alcance previsto para o conceito necessidades educacionais especiais (sic). 
A Resolução CNE/CEB n 2/2001 representa, portanto, um marco na apropriação da efetiva concepção de inclusão no Brasil, finalmente tendente a desenvolvê-la como parte da educação geral e não mais como uma subespécie de educação, distinta e incompatível com aquela prestada a pessoas sem deficiência.

Apesar da expressa priorização da inserção do aluno com deficiência nas classes regulares, as Diretrizes Nacionais para a Educação Especial na Educação Básica (BRASIL, 2001b) estabelecem, extraordinariamente, a possibilidade de inserção dos "alunos que apresentem dificuldades acentuadas de aprendizagem ou condições de comunicação e sinalização diferenciados dos demais alunos e demandem ajudas e apoios intensos e contínuos” em classes especiais, criadas excepcionalmente pelas escolas (artigo 9º da Resolução CNE/CEB nº 2/2001) ou, ainda, em escolas especiais, quando as adaptações necessárias para atendimento da necessidade do aluno sejam tão significativas que a escola comum não consiga prover (artigo 10, da Resolução CNE/CEB no 2/2001).

Em ambas as hipóteses essa situação pode ser transitória, de forma que a partir da objetivação do desenvolvimento do aluno na classe ou escola especial, a equipe pedagógica e a família devem analisar, a partir de uma avaliação pedagógica, e decidir conjuntamente quanto ao retorno do aluno à classe e escola comuns (artigo $9^{\circ}, \S 2^{\circ}$ e artigo $10, \S 3^{\circ}$, da Resolução CNE/CEB nº 2/2001).

No Censo de 2000 (INSTITUTO..., 2000) foi constatada uma população de 24.600.256 pessoas com algum tipo de deficiência, o que correspondia a 14,5\% da população brasileira. Verificou-se entre os Censos de 1991 e o de 2000 um aumento superior a 13 pontos percentuais no número de pessoas com deficiência no Brasil, que era de $1,41 \%$ da população total. 
Esse aumento é atribuído, em parte, à ampliação do escopo da definição de deficiência para fins censitários, o que interfere na comparação desses dados (LENZI, 2012). ${ }^{26}$

À época da publicação da Resolução CNE/CEB n. 2/2001 e o estabelecimento das Diretrizes Nacionais para a Educação Especial na Educação Básica, já se verificava o início de ações conceitualmente inclusivas no Brasil. O Instituto Nacional de Estudos e Pesquisas Educacionais Anísio Teixeira - INEP - coordena e realiza anualmente o Censo Escolar tanto da Educação Básica (ensino regular, educação especial, educação de jovens e adultos e educação profissional) quanto do Ensino Superior. É feito um levantamento de dados estatísticos educacionais para delineamento de um panorama nacional da educação, servindo como referência para análise e redefinição de políticas públicas na área da educação, além de subsidiar a execução de programas nessa área (INSTITUTO..., 2016a).

Antes mesmo da Resolução CNE/CEB n. 2/2001, desde 1998, o Censo Escolar da Educação Básica ${ }^{27}$ já levantava dados de matrículas de alunos com deficiência em classes comuns, seja com recursos especiais ou não. Os preceitos constitucionais de atendimento educacional aos portadores de deficiência preferencialmente na rede regular de ensino (artigo 208, III, CF/88) e as premissas da Conferência Mundial sobre Necessidades Especiais em Salamanca, em 1994, de acesso da pessoa com deficiência

\footnotetext{
${ }^{26}$ Lenzi (2012) alerta para a dificuldade de realizar comparações de dados coletados em Censos Demográficos distintos, assim como em pesquisas de outra natureza, ainda que mais específicas sobre a pessoa com deficiência, tendo em vista a variabilidade dos conceitos utilizados na formulação de cada deficiência, suas características e do grau de severidade. Nesse sentido, a autora esclarece a importância da análise, mas alerta para a possibilidade efetiva de distorções ao se fazer uma série histórica utilizando os dados do Censo, por exemplo.

${ }^{27}$ Até 1997, o tipo de escola ou classe em que a pessoa com deficiência estava inserida não era objeto de recenseamento.
} 
à escola regular, já, de alguma forma, subsidiaram ações de promoção da inclusão escolar, notadamente a participação de alunos com deficiência em salas comuns.

Dessa forma, em 1998, por meio do Censo Escolar da Educação Básica, constatou-se que 48.868.491 alunos foram matriculados em um dos níveis da Educação Básica (Educação Infantil, Ensino Fundamental e Ensino Médio). Em relação às pessoas com deficiência, foram identificadas 293.403 alunos com deficiência matriculados em escolas exclusivamente especializadas ou em classes especiais de escola regular (entre eles 57.287 alunos com deficiência visual, auditiva ou física; 170.134 com deficiência mental; 40.593, com deficiência múltipla; 25.389 com outras necessidades especiais). Nesse mesmo censo escolar de 1998, já se identificaram 43.923 alunos com deficiência matriculados em classes comuns das escolas regulares, sendo 18.488 em salas comuns com recursos específicos para sua inclusão (entre eles 6.593 alunos com deficiência visual, auditiva ou física; 5.050 com deficiência mental; 594 com deficiência múltipla; 25.389 com outras necessidades especiais) e 25.435 em salas comuns sem recursos inclusivos específicos (entre eles 10.640 alunos com deficiência visual, auditiva ou física; 6.193 com deficiência mental; 1.395 com deficiência múltipla; 7.207 com outras necessidades especiais) (INSTITUTO..., 2016b).

O percentual de alunos com deficiência matriculados, considerando-se tanto aqueles inscritos em escolas especializadas ou salas especiais como os frequentadores de classes comuns na rede regular de ensino, é de $0,69 \%$ do total de alunos computados naquele ano na Educação Básica. E considerando-se apenas os inseridos em classes comuns na rede regular de ensino, essa participação ainda é menor, correspondendo a 0,09\% dos matriculados no total.

O número de matrículas ainda é reduzido, se considerarmos que, com base no Censo realizado em 1991, a população de pessoas com deficiência era de 1,14\% da população brasileira. Inobstante essa disparidade em 
relação ao percentual da população de pessoas com deficiência e matrículas na Educação Básica, é possível verificar alguns aspectos importantes para o percurso da inclusão ainda incipiente naquele momento no Brasil.

Muito embora fosse possível imaginar que esse primeiro registro de inclusão do aluno com deficiência em classes comuns pudesse se restringir a problemas físicos, verifica-se que $25,6 \%$ do total de alunos com deficiência matriculados em classes comuns têm deficiência mental. Desde os primeiros registros dessa ação inclusiva, de fato já se inseriam na rede regular de ensino, em salas comuns, pessoas com deficiências diversas, em uma expressão efetiva de sua inclusão pelo menos no que se refere à matrícula nessas instituições de ensino. Outros fatores inerentes à inclusão precisam ser considerados para verificação da sua efetividade, a exemplo da capacitação de professores e de aspectos metodológicos necessários à prestação de serviço educacional inclusivo e adequado.

O Brasil demonstrava, naquele momento, maturidade no que se refere a sua legislação, ao já legitimar a inclusão nesses moldes, o que será absolutamente compatível com o estabelecido nos anos seguintes no primeiro tratado internacional de Direitos Humanos do Século 21, a Convenção Internacional sobre os Direitos das Pessoas com Deficiência.

Com status formal de emenda constitucional, ${ }^{28}$ a Convenção Internacional sobre os Direitos das Pessoas com Deficiência, aprovada no Brasil

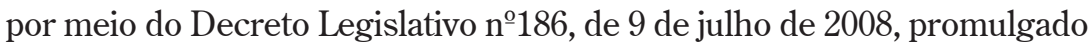
pelo Decreto $\mathrm{n}^{\circ}$ 6.949, de 25 de agosto de 2009, assegura o sistema educacional inclusivo em todos os níveis, assim garantindo que as pessoas com deficiência, de qualquer idade, não sejam excluídas do sistema educacional geral, em nenhum nível, sob alegação de deficiência, assim como que recebam o apoio necessário, no âmbito desse mesmo sistema educacional geral, com vistas a facilitar sua efetiva educação.

${ }^{28}$ Artigo $5^{\circ}, \S 3$, da Constituição Federal brasileira. 
A Convenção insere no texto constitucional importante tratamento ao direito fundamental à educação, na medida em que amplia a abrangência constitucional do direito à educação da pessoa com deficiência. Nesse contexto, observa-se a consolidação do modelo social da deficiência, que retira da esfera exclusivamente privada as questões inerentes à inclusão. A deficiência, definitivamente, passa a ser uma questão de interação da pessoa com o meio em que vive, de forma que a sociedade não mais pode ser vista como sujeito passivo nessa relação com a deficiência. Deficientes também são o espaço, o serviço, os sujeitos que não permitem a inclusão.

Assim, o dever de adaptação razoável e de não discriminação são elementos intrínsecos ao modelo social de deficiência, de forma que essa corresponsabilidade do meio, dos sujeitos que interagem com a pessoa com deficiência, é da essência da própria inclusão.

O direito à educação da pessoa com deficiência é tratado no artigo 24 da Convenção Internacional sobre os Direitos das Pessoas com Deficiência (BRASIL, 2009), que estabelece em seu primeiro item:

1. Os Estados Partes reconhecem o direito das pessoas com deficiência à educação. Para efetivar esse direito sem discriminação e com base na igualdade de oportunidades, os Estados Partes assegurarão sistema educacional inclusivo em todos os níveis, bem como o aprendizado ao longo de toda a vida, com os seguintes objetivos:

a) O pleno desenvolvimento do potencial humano e do senso de dignidade e autoestima, além do fortalecimento do respeito pelos direitos humanos, pelas liberdades fundamentais e pela diversidade humana;

b) O máximo desenvolvimento possível da personalidade e dos talentos e da criatividade das pessoas com deficiência, assim como de suas habilidades físicas e intelectuais;

c) A participação efetiva das pessoas com deficiência em uma sociedade livre. 
A Convenção dispõe, ainda, no item II, do artigo 24, que cabe aos Estados-Partes assegurarem que as pessoas com deficiência sejam incluídas no sistema educacional geral, não permitindo quaisquer exclusões em decorrência de sua deficiência, de forma que lhes seja garantido acesso ao ensino primário inclusivo, de qualidade e gratuito, assim como ao ensino secundário em igualdade de condições com as demais pessoas da comunidade em que se inserem. Para tanto a Convenção, também especificamente em relação ao direito à educação, estabelece o dever de adaptação razoável, conforme as necessidades individuais de cada um, assim como objetiva que sejam tomadas medidas de apoio que garantam a efetiva educação das pessoas com deficiência, para maximização do seu desenvolvimento acadêmico e social, a fim de concretização da meta de inclusão plena.

A fim de atender ao disposto no referido artigo 24 da Convenção, foi publicado o Decreto 7.611, de 17 de novembro de 2011, que adéqua a legislação infraconstitucional brasileira ao disposto na Convenção, assim como especificamente estabelece o dever do Estado com a educação das pessoas público-alvo da educação especial a ser efetivado com "a garantia de um sistema educacional inclusivo em todos os níveis, sem discriminação e com base na igualdade de oportunidades” (artigo $\left.1^{\circ}, \mathrm{I}\right)$.

Ao garantir serviços de apoio especializado, o Decreto 7.611/2011, em seu artigo $2^{\circ}, \S 2^{\circ}$, esclarece que:

Art. $2^{\circ}(\ldots)$

$\S 2^{\circ} \mathrm{O}$ atendimento educacional especializado deve integrar a proposta pedagógica da escola, envolver a participação da família para garantir pleno acesso e participação dos estudantes, atender às necessidades específicas das pessoas público-alvo da educação especial, e ser realizado em articulação com as demais políticas públicas.

E continua, ao traçar os objetivos desse atendimento, estabelecendo que: 
Art. $3^{\circ}$ São objetivos do atendimento educacional especializado:

I - prover condições de acesso, participação e aprendizagem no ensino regular e garantir serviços de apoio especializados de acordo com as necessidades individuais dos estudantes;

II - garantir a transversalidade das ações da educação especial no ensino regular;

III - fomentar o desenvolvimento de recursos didáticos e pedagógicos que eliminem as barreiras no processo de ensino e aprendizagem; e IV - assegurar condições para a continuidade de estudos nos demais níveis, etapas e modalidades de ensino.

Fica estabelecido no ordenamento jurídico brasileiro o alcance da concepção da educação inclusiva, em que na mesma medida que estabelece $o$ atendimento às necessidades específicas das pessoas com deficiência, igualmente priorizam sua inserção no ensino regular, garantindo sua participação e desenvolvimento escolar pleno.

Com a mesma data de publicação foi instituído o Plano Nacional dos Direitos das Pessoas com Deficiência - Plano Viver sem limites -, em 17 de novembro de 2011, mais um mecanismo de garantia dos direitos e inclusão das pessoas com deficiência no Brasil. Nesse Plano mais uma vez a o direito à educação por parte das pessoas com deficiência recebe tratamento específico a fim de garantir-lhes o acesso e fruição, sendo uma de suas diretrizes a "garantia de um sistema educacional inclusivo" e um dos eixos de sua atuação o acesso à educação (artigo $3^{\circ}$, I, e artigo $4^{\circ}$, I).

O gráfico abaixo indica a população brasileira total e o número de pessoas com deficiência com base nos últimos três Censos Demográficos (IBGE, online) brasileiros: 
Gráfico 1 - População brasileira total e pessoas com deficiência - Censos 1991,2000 e 2010

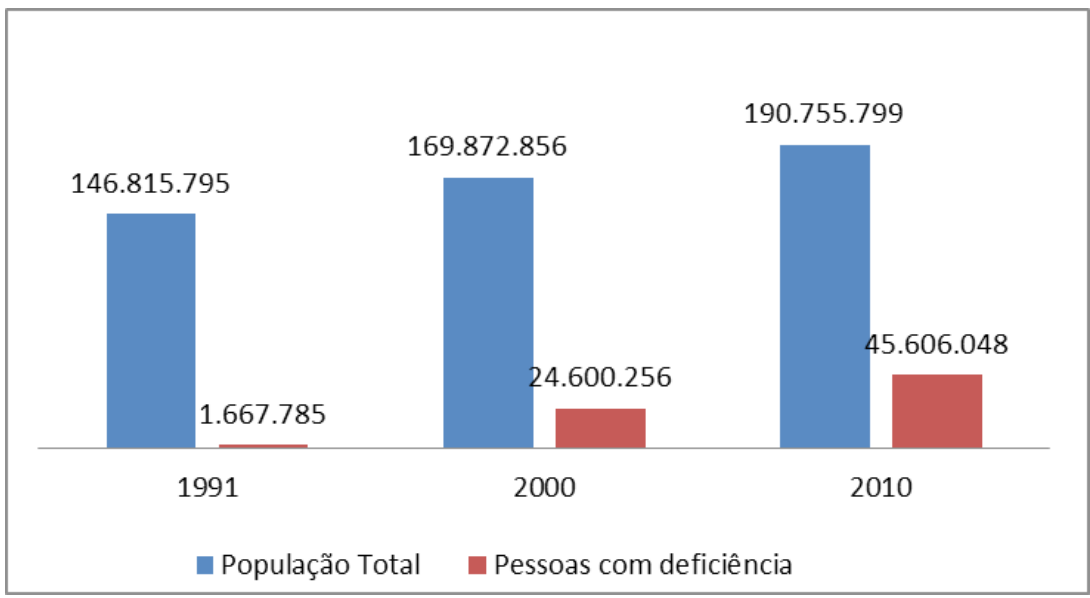

Fonte: Elaboração própria, com base nos Censos Demográficos 1991/2000/2010 (INSTITUTO..., 2016b).

Com base nos dados dos Censos Demográficos de 1991, 2000 e 2010, o número de pessoas com deficiência não teve um crescimento uniforme, o que é coerente diante da grande variabilidade da concepção de deficiência em cada um desses levantamentos. Em 1991 praticamente foram recenseadas as pessoas com deficiência com base em um modelo inerente às características corporais (subdividida em física ou mental).

Em 2000, verificou-se uma ampliação do conceito de deficiência, com perguntas que abrangiam as dimensões dos domínios da visão, da audição, da mobilidade e da dificuldade de comunicação. A formulação dos quesitos era mais extensa e com caráter mais subjetivo (“Como avalia a sua capacidade de...”). No Censo de 2010 as perguntas foram mais diretas (“Tem dificuldade permanente de ...”), deixando maior clareza para o respondente, assim como foi incluída a investigação acerca do domínio dos cuidados pessoais. No último Censo também ficou explícita a inclusão 
apenas de pessoas com deficiências permanentes, não sendo consideradas aquelas com dificuldades temporárias decorrentes de acidentes, por exemplo.

Esses fatores favoreceram a ampliação do contingente da população daqueles que se identificaram como pessoas com deficiência, de forma que se percebe uma variação na série histórica diante da diferença de parâmetros entre os conceitos e tipos de deficiências inseridas em cada um desses censos (BORGES, 2010). Considerando os três últimos censos, a proporção de pessoas com deficiência variou de 1,14\% a 23,91\% em relação à totalidade da população. No que se refere à proporção de pessoas com deficiência em função da população brasileira em cada um desses recenseamentos, tem-se que em 2000, em comparação com o Censo de 1991, houve um aumento populacional no Brasil de 15,70\%, enquanto o crescimento do número de pessoas com deficiência foi de $1.375 \%$. Já em 2010, em relação ao Censo de 2000, a população brasileira cresceu 12,29\%, enquanto o aumento da população de pessoas com deficiência, no mesmo período, foi de $85,39 \%$.

O crescimento do número de pessoas com deficiência não acompanhou o aumento populacional do restante da população brasileira, de forma que se pode concluir que a falta de padronização dos parâmetros da conceituação de deficiência acarreta a impossibilidade de comparabilidade, uma vez que capta perfis distintos sobre deficiência.

Outro parâmetro importante para análise da inclusão, sob a premissa do modelo social da deficiência, são os dados inerentes à quantidade de pessoas com deficiência matriculadas em a) em escolas exclusivamente especializados ou em classes especiais de escola regular e b) em classes comuns de escola regular. Somente a partir de 1998 o Inep passou a coletar dados com esse detalhamento, o que representa o primeiro marco censitário quanto à percepção de diferentes naturezas de escolas ou classes passíveis de prestação dos serviços de educação especial. 
Os dados a seguir foram coletados das Sinopses Estatísticas da Educação Básica do Inep e permitem fazer uma análise da educação especial no Brasil no período compreendido entre 1998 e $2014 .^{29}$

Tabela 1 - Descrição do número de alunos matriculados na educação básica e alunos com deficiência em classes comuns e em classes especiais

\begin{tabular}{|c|c|c|c|c|}
\hline ANO & $\begin{array}{l}\text { Total de } \\
\text { alunos matri- } \\
\text { culados }\end{array}$ & $\begin{array}{c}\text { Total de } \\
\text { alunos com } \\
\text { deficiência } \\
\text { matriculados }\end{array}$ & $\begin{array}{c}\text { Alunos com defi- } \\
\text { ciência matricu- } \\
\text { lados em classes } \\
\text { comuns de escola } \\
\text { regular* }\end{array}$ & $\begin{array}{c}\text { Alunos com deficiência } \\
\text { matriculados em escolas } \\
\text { exclusivamente especializa- } \\
\text { dos ou em classes especiais } \\
\text { de escola regular }\end{array}$ \\
\hline 1998 & 50.559 .724 & 247.326 & 43.923 & 203.403 \\
\hline 1999 & 49.606 .435 & 374.699 & 63.345 & 311.354 \\
\hline 2000 & 54.537 .472 & 382.215 & 81.695 & 300.520 \\
\hline 2001 & 55.627 .025 & 404.743 & 81.344 & 323.399 \\
\hline 2002 & 54.716 .609 & 448.601 & 110.704 & 337.897 \\
\hline 2003 & 55.265 .848 & 504.039 & 145.141 & 358.898 \\
\hline 2004 & 56.174 .997 & 566.753 & 195.370 & 371.383 \\
\hline 2005 & 56.471 .622 & 492.908 & 114.834 & 378.074 \\
\hline 2006 & 55.942 .047 & 511.919 & 136.431 & 375.488 \\
\hline 2007 & 52.179 .530 & 646.663 & 304.882 & 341.781 \\
\hline 2008 & 52.321 .667 & 690.090 & 374.537 & 315.553 \\
\hline 2009 & 52.580 .452 & 638.718 & 387.031 & 252.687 \\
\hline 2010 & 51.549 .889 & 702.603 & 484.332 & 218.271 \\
\hline 2011 & 50.972 .619 & 752.305 & 558.423 & 193.882 \\
\hline 2012 & 50.545 .050 & 820.433 & 620.777 & 199.656 \\
\hline 2013 & 50.042 .448 & 843.342 & 648.921 & 194.421 \\
\hline 2014 & 49.771.371 & 886.815 & 698.768 & 188.047 \\
\hline
\end{tabular}

Fonte: Elaboração própria, tendo como fonte as informações do MEC/Inep/Sinopses Estatísticas da Educação Básica (INSTITUTO..., 2016b).

* Assim consideradas as classes comuns com ou sem recursos multifuncionais.

${ }^{29}$ Até a data de finalização da presente pesquisa, os dados do Censo da Educação Básica referentes ao ano de 2015 ainda não estavam disponíveis no site do Inep. 
Uma primeira análise dos dados do Censo da Educação Básica revela o crescimento do número de alunos com algum tipo de deficiência matriculados nessa etapa escolar (que compreende a Educação Infantil, o Ensino Fundamental, o Ensino Médio, a Educação de Jovens e Adultos e o Ensino Profissional). No período de 1998 a 2014 verifica-se um crescimento de 258,56\% de matrícula de alunos com deficiência, o que não representa o mesmo movimento quanto ao total de matrículas no mesmo período.

Gráfico 2 - Total de alunos matriculados na Educação Básica - 1998 a 2014

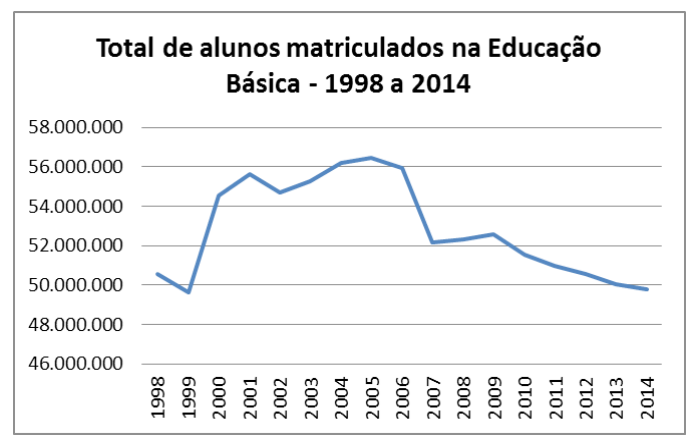

Fonte: Elaboração própria, tendo como fonte as informações do MEC/Inep/ Sinopses Estatísticas da Educação Básica (INSTITUTO..., 2016b).

Gráfico 3 - Total de alunos com deficiência matriculados na Educação Básica - 1998 a 2014

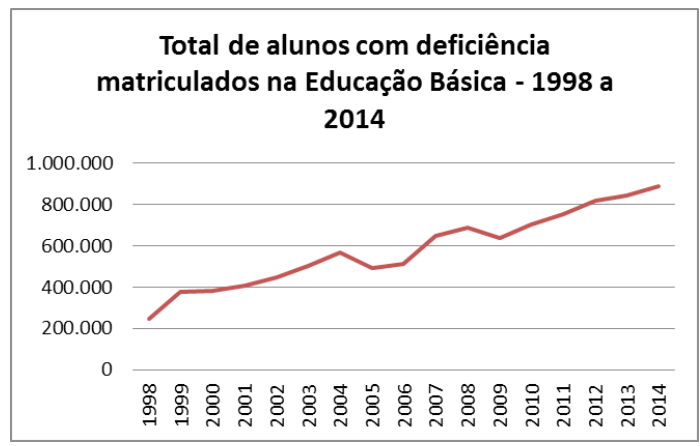

Fonte: Elaboração própria, tendo como fonte as informações do MEC/Inep/ Sinopses Estatísticas da Educação Básica (INSTITUTO..., 2016b). 
No que se refere especificamente à matrícula de pessoas com deficiências, algumas variáveis merecem destaque. Nos anos de 1998 a 2004 as sinopses estatísticas não apresentam um resumo da totalidade de matrículas, de forma que todas as modalidades ou etapas escolares eram detalhadas individual e separadamente. Ao se tratar da Educação Especial, verifica-se a ênfase (detalhamento por série, sexo, raça, etc.) dada às informações dos alunos com deficiência matriculados em escolas exclusivamente especializadas ou em classes especiais de escolas regulares. Nas poucas planilhas dedicadas à Educação Especial referente às matrículas de alunos com deficiência em classes comuns de escolas regulares, constata-se a inserção da palavra "integração" entre parênteses nos seus títulos, demonstrando a fase em que se encontrava, de fato, a percepção da deficiência no país.

Nos Censos da Educação Básica de 2005 e 2006, a primeira planilha da Sinopse Estatística trazia o detalhamento das matrículas na Educação Básica com indicação dos dados absolutos por etapas e modalidades de ensino (Educação Infantil, Ensino Fundamental, Ensino Médio, Educação Especial, Educação de Jovens e Adultos e Ensino Profissional). Nessa síntese, o número de alunos matriculados na Educação Especial era somente o daqueles inseridos em escolas exclusivamente especializadas ou em classes especiais de escolas regulares. O número de alunos com deficiência matriculados na rede regular de ensino em salas comuns tão somente era mencionado em tabela específica ao final do relatório.

Em 2007 e 2008 não houve esse compilamento das matrículas por etapas e modalidades de ensino em uma única planilha.

A partir de 2009 o Censo voltou a apresentar uma primeira planilha com a síntese dos dados absolutos e, desde então, ao tratar da Educação Especial, já a insere em duas categorias, matrículas em escolas exclusivamente especializados ou em classes especiais de escola regular e matrícu- 
las em classes comuns de escola regular, dando igual tratamento a ambas, diferentemente do que ocorrera nos Censos em que se observou essa síntese nos anos anteriores.

As premissas da Resolução CNE/CEB n. 2/2001, e, portanto, das instituídas Diretrizes Nacionais para a Educação Especial na Educação Básica, passam a ser percebidas concretamente, quanto aos critérios de recenseamento, a partir do Censo da Educação Básica de 2009. Constata-se com a mudança de tratamento das modalidades de matrícula das pessoas com deficiência, em uma primeira perspectiva, um passo importante para a percepção nos Censos da Educação Básica da deficiência no seu modelo social, como barreiras a serem enfrentadas coletivamente, com a sociedade como um todo sendo o sujeito ativo desse processo de mudança.

A evolução do número de matrículas em cada uma dessas categorias no período de 1998 a 2014 também evidencia uma mudança de comportamento e, pode-se concluir, a gradativa construção da inclusão da pessoa com deficiência na escola regular, em classes comuns, em substituição à primazia original da inserção desses alunos em escolas exclusivamente especializadas ou em classes especiais, ainda que em escolas regulares.

Gráfico 4 - Evolução de matrículas 1998 - 2014

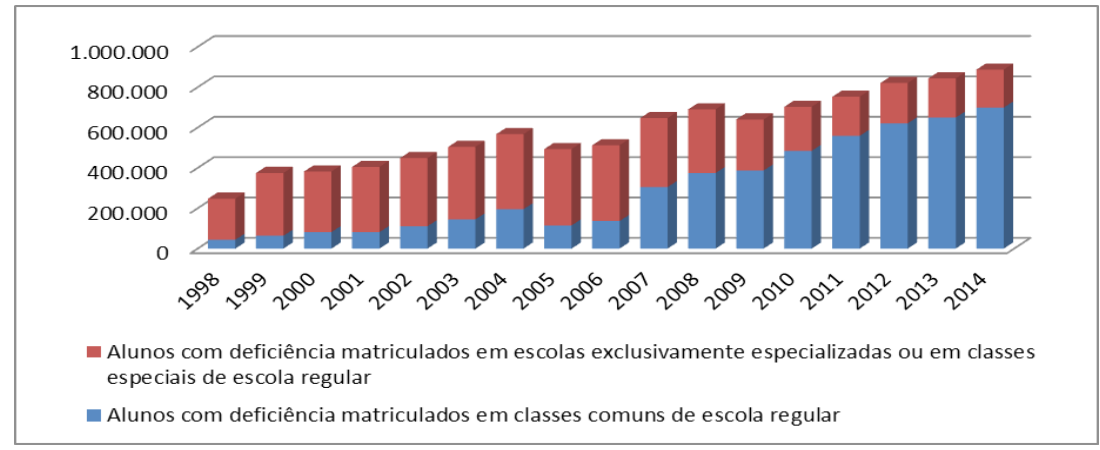

Fonte: Elaboração própria, tendo como fonte as informações do MEC/Inep/ Sinopses Estatísticas da Educação Básica (INSTITUTO..., 2016b). 
Não somente houve uma evolução expressiva do número de matrículas de alunos com deficiência como um todo (aumento de 258,56\%, no período de 1998 a 2014), como também uma verdadeira inversão do percentual de matrículas ocupadas por alunos na rede especializada (escola e classes) e em classes comuns na rede regular (com ou sem recursos específicos).

Gráficos 5, 6, 7, 8 e 9 - Evolução do número de matrículas na educação especial -1998 a 2014

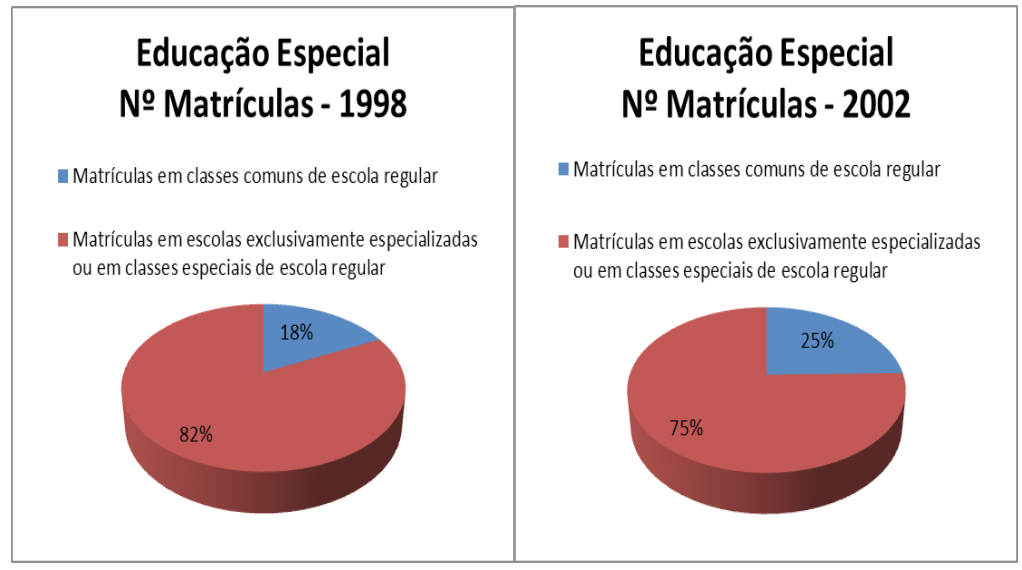

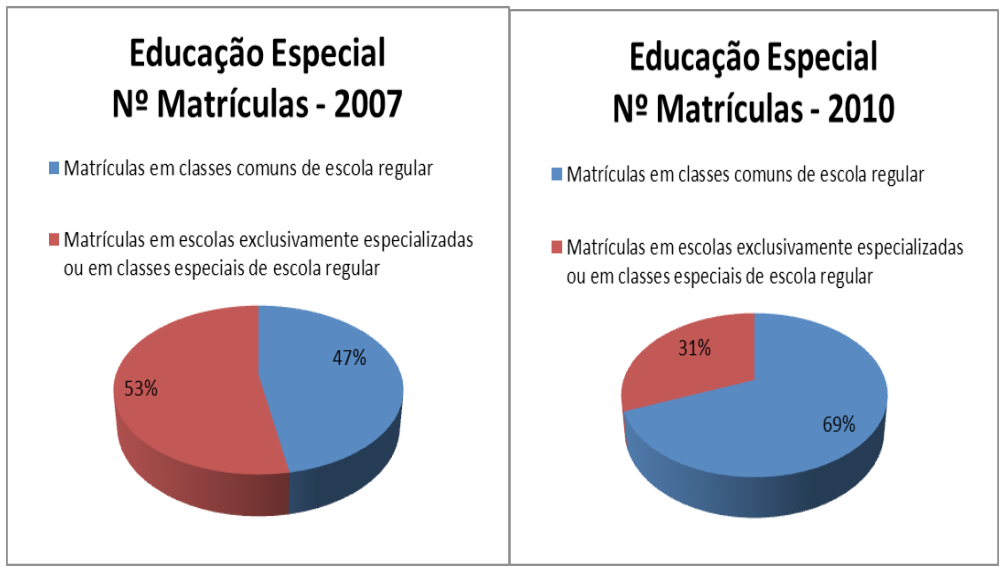




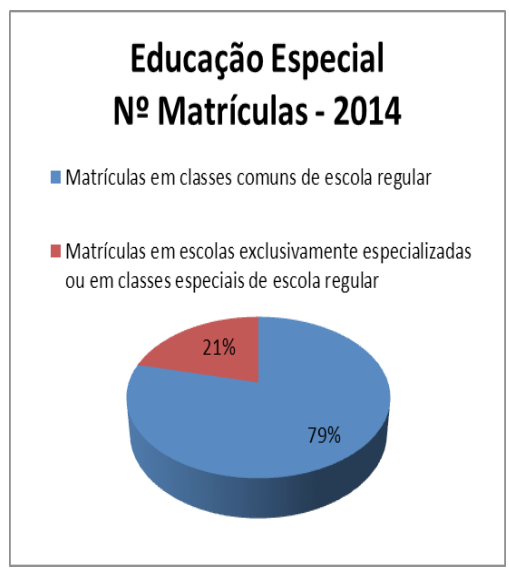

Fonte: Elaboração própria, tendo como fonte as informações do MEC/ Inep/Sinopses Estatísticas da Educação Básica (INSTITUTO..., 2016b).

Tais dados demonstram a efetiva evolução do número de alunos com deficiência matriculados na rede regular de ensino, em salas comuns, com ampla possibilidade de convívio social com os demais alunos e instituição efetiva de sua inclusão. Esse é apenas um dos aspectos que podem evidenciar a inclusão da pessoa com deficiência na escola, devendo-se analisar também as condições de prestação do serviço educacional inclusivo considerando-se questões tais como formação docentes e as efetivações curriculares, pedagógicas e infraestruturais necessárias para sua concretude.

Especificamente no que se refere ao número de matrículas de pessoas com deficiência no Ensino Superior, o Inep aponta um crescimento de $1.125,81 \%$, igualmente demonstrando a inserção cada vez maior dos estudantes com deficiência egressos do Ensino Médio nas universidades. 
Tabela 2 - Alunos com deficiência matriculados no Ensino Superior 2000 $-2014$

\begin{tabular}{cc}
\hline Ano & $\begin{array}{c}\text { No de Alunos com Deficiência matriculados no } \\
\text { Ensino Superior }\end{array}$ \\
\hline 2000 & 2.173 \\
2001 & 2.898 \\
2002 & 2.425 \\
2003 & 5.078 \\
2004 & 5.395 \\
2005 & 6.327 \\
2006 & 6.960 \\
2007 & 6.943 \\
2008 & 12.018 \\
2009 & 20.530 \\
2010 & 19.869 \\
2011 & 22.455 \\
2012 & 26.663 \\
2013 & 29.221 \\
2014 & 26.637 \\
\hline
\end{tabular}

Fonte: Elaboração própria a partir dos dados disponibilizados pelo Inep (INSTITUTO..., 2016b).

A legislação brasileira vem evoluindo no que diz respeito à tratativa dos direitos das pessoas com deficiência, assim como da delimitação dessa população, no intuito de melhor prover sua inclusão e garantir a efetividade de seus direitos. Assim ocorreu em relação às pessoas com transtorno do espectro autista. A Lei 12.764, de 27 de dezembro de 2012, institui a chamada Política Nacional de Proteção dos Direitos da Pessoa com Transtorno do Espectro Autista, reconhecendo-a como pessoa com deficiência para todos os efeitos legais (artigo $1^{\circ}$, $2^{\circ}$ ) e estabelece em seu artigo 3, inciso IV, alínea "a”, o direito ao acesso da pessoa com transtorno do espectro autista à educação e ao ensino profissionalizante.

Em 6 de julho de 2015 foi publicada a Lei $\mathrm{n}^{\mathrm{0}}$ 13.146, o Estatuto da Pessoa com Deficiência. Tendo tramitado desde 21 de dezembro de 2006, por meio do Projeto de Lei $n^{0} 7.699$, de iniciativa do senador Paulo Paim, o Estatuto da Pessoa com Deficiência estabelece as diretrizes gerais, normas 
e critérios básicos para assegurar, promover e proteger o exercício pleno e em condições de igualdade de todos os direitos humanos e liberdades fundamentais pelas pessoas com deficiência, visando a sua inclusão social e cidadania participativa plena e efetiva.

Seu texto sistematiza a regulamentação acerca da garantia dos direitos das pessoas com deficiência, inclusive a educação, assim como estabelece as obrigações estatais para sua efetividade. Já compatível com as premissas da Convenção Internacional sobre os Direitos da Pessoa com Deficiência, o Estatuto adota a concepção social da deficiência, de forma que em seu artigo $2^{\circ}$ estabelece:

Considera-se pessoa com deficiência aquela que tem impedimento de longo prazo de natureza física, mental, intelectual ou sensorial, o qual, em interação com uma ou mais barreiras, pode obstruir sua participação plena e efetiva na sociedade em igualdade de condições com as demais pessoas.

Assim, estabelece em seu artigo $4^{0}$ o direito das pessoas com deficiência à igualdade de oportunidades com as demais pessoas, protegendo-as de quaisquer espécies de discriminação, que conceitua nesse mesmo artigo, em seu $\S 1^{\circ}$.

Considera-se discriminação em razão da deficiência toda forma de distinção, restrição ou exclusão, por ação ou omissão, que tenha o propósito ou o efeito de prejudicar, impedir ou anular o reconhecimento ou o exercício dos direitos e das liberdades fundamentais de pessoa com deficiência, incluindo a recusa de adaptações razoáveis e de fornecimento de tecnologias assistivas.

O Estatuto, portanto, atende às disposições constitucionais constantes na Convenção, de forma a regulamentar direitos e deveres tendentes a sua concretização. Em relação ao direito à educação da pessoa com deficiência, a grande inovação do Estatuto é consolidar o entendimento jurisprudencial majoritário, estabelecendo, em seu artigo $28, \S 1^{\circ}$, que é 


\section{“vedada a cobrança de valores adicionais de qualquer natureza em suas}

mensalidades, anuidades e matrículas no cumprimento dessas determinações”, que se referem às adaptações dispostas em seus incisos I, II, III, V, VII, VIII, IX, X, XI, XII, XIII, XIV, XV, XVI, XVII e XVIII ${ }^{30}$ quando o serviço for prestado por instituição privada.

${ }^{30}$ Artigo 28. Incumbe ao poder público assegurar, criar, desenvolver, implementar, incentivar, acompanhar e avaliar: I - sistema educacional inclusivo em todos os níveis e modalidades, bem como o aprendizado ao longo de toda a vida; II - aprimoramento dos sistemas educacionais, visando a garantir condições de acesso, permanência, participação e aprendizagem, por meio da oferta de serviços e de recursos de acessibilidade que eliminem as barreiras e promovam a inclusão plena; III - projeto pedagógico que institucionalize o atendimento educacional especializado, assim como os demais serviços e adaptações razoáveis, para atender às características dos estudantes com deficiência e garantir o seu pleno acesso ao currículo em condições de igualdade, promovendo a conquista e o exercício de sua autonomia; IV - oferta de educação bilíngue, em Libras como primeira língua e na modalidade escrita da língua portuguesa como segunda língua, em escolas e classes bilíngues e em escolas inclusivas; V - adoção de medidas individualizadas e coletivas em ambientes que maximizem o desenvolvimento acadêmico e social dos estudantes com deficiência, favorecendo o acesso, a permanência, a participação e a aprendizagem em instituições de ensino; VI - pesquisas voltadas para o desenvolvimento de novos métodos e técnicas pedagógicas, de materiais didáticos, de equipamentos e de recursos de tecnologia assistiva; VII - planejamento de estudo de caso, de elaboração de plano de atendimento educacional especializado, de organização de recursos e serviços de acessibilidade e de disponibilização e usabilidade pedagógica de recursos de tecnologia assistiva; VIII - participação dos estudantes com deficiência e de suas famílias nas diversas instâncias de atuação da comunidade escolar; IX - adoção de medidas de apoio que favoreçam o desenvolvimento dos aspectos linguísticos, culturais, vocacionais e profissionais, levando-se em conta o talento, a criatividade, as habilidades e os interesses do estudante com deficiência; $\mathrm{X}$ - adoção de práticas pedagógicas inclusivas pelos programas de formação inicial e continuada de professores e oferta de formação continuada para o atendimento educacional especializado; XI - formação e disponibilização de professores para o atendimento educacional especializado, de tradutores e intérpretes da Libras, de guias intérpretes e de profissionais de apoio; XII - oferta de ensino da Libras, do Sistema Braille e de uso de recursos de tecnologia assistiva, de forma a ampliar habilidades funcionais dos estudantes, promovendo sua autonomia e participação; XIII - acesso à educação superior e à educação profissional e tecnológica em igualdade de oportunidades e condições com as demais pessoas; XIV - inclusão em conteúdos curriculares, em cursos de nível superior e de educação profissional técnica e tecnológica, de temas relacionados à pessoa com deficiência nos respectivos campos de conhecimento; $\mathrm{XV}$ - acesso da pessoa com deficiência, em igualdade de condições, a jogos e a atividades recreativas, esportivas e de lazer, no sistema escolar; XVI - acessibilidade para todos os estudantes, trabalhadores da educação e demais integrantes da comunidade escolar às edificações, aos ambientes e às atividades concernentes a todas as modalidades, etapas e níveis de ensino; XVII - oferta de profissionais de apoio escolar; XVIII - articulação intersetorial na implementação de políticas públicas. 
Muito embora não disponha textualmente acerca da inclusão da pessoa com deficiência na rede regular de ensino, e até chegue mesmo a dar ênfase às obrigações de atendimento especializado, o Estatuto mantém essa diretriz na medida em que dispõe acerca da inclusão plena, de forma que assim será inserção em salas regulares, quando essa for a expressão da mais adequada e plena inclusão. Da mesma forma que, não sendo essa a melhor medida no caso específico, deve-se prestar o serviço especializado com as garantias de efetividade que lhes forem inerentes. Essas garantias estão dispostas em diversos incisos no citado artigo 28 e de forma muito específica nos incisos I e II, ao se estabelecer a obrigação de promover um sistema educacional inclusivo em todos os níveis e modalidades, bem como o aprendizado ao longo de toda a vida, além de seu aprimoramento visando a garantir condições de acesso, permanência, participação e aprendizagem, por meio da oferta de serviços e de recursos de acessibilidade que eliminem as barreiras e promovam a inclusão plena.

\section{CONCLUSÕES}

Apesar de o século 20 ter sido palco de notória e importante evolução legislativa no que se refere à garantia do direito à educação de pessoas com deficiência, sob a inspiração dos preceitos de respeito à dignidade humana e à igualdade, a efetiva conotação dada à educação inclusiva estava restrita a características de integração. Considera-se que esse já foi um grande avanço, tendo em vista as percepções históricas que a precederam, inclusive legislativas, notadamente o amparo estatal da absoluta discriminação e abandono da pessoa com deficiência, seguida da intervenção assistencial pelo Estado (o que mantinha, de certa forma, o isolamento social das pessoas tidas como limitadas ou defeituosas).

A Declaração Universal dos Direitos Humanos (ORGANIZAÇÃO..., 1948) foi preponderante para a superação dessa visão assistencialista, mas o movimento de consolidação do direito à educação inclusiva das pessoas 
com deficiência passaria primeiro por uma fase de integração, muito mais por uma evolução natural do tratamento assistencialista anterior do que por negação à efetiva educação inclusiva.

A humanidade aprendeu gradativamente no último século os contornos dessa educação. A garantia de integração parecia adequada, mas a prática demonstrou não ser muito mais que desigualdade institucionalizada. Cabia à pessoa com deficiência enquadrar-se à sociedade, que permanecia estática.

Percebeu-se que o que se pretendia era maior do que isso. Era a inserção da pessoa com deficiência nos ambientes regulares de educação. Muito embora em muitas oportunidades a legislação pátria, e mesmo os ditames internacionais, tratem equivocadamente a inclusão por integração, em suas premissas declaravam o direito supremo de tratamento isonômico como garantia de respeito à dignidade humana. Inclusão, portanto, pressupõe a participação da sociedade como um todo. Cabe ao Estado e à sociedade o combate à exclusão, por meio da oferta de reais condições de inserção social. Não se trata, portanto, de simples adaptação, mas diferentemente da integração, da tomada de medidas positivas para evitar a exclusão.

Analisando-se as disposições legislativas, desde o imperativo constitucional no mesmo sentido, acerca do direito à educação de qualidade em igualdade de condições para o acesso e permanência na escola com garantia de padrão de qualidade, é possível concluir que as disposições legislativas para efetividade da acessibilidade e inclusão escolar na atual concepção data concretamente no Brasil de 2001, com a Resolução CNE/ CEB n. 2/2001, do Conselho Nacional de Educação - CNE -, que estabelece as Diretrizes Nacionais para a Educação Especial na Educação Básica, constituindo documento fundamental das proposições nacionais voltadas à educação inclusiva. 
O dever de prestação do serviço educacional em igualdade de condições às pessoas com deficiência consolida-se, contudo, com a Convenção Internacional sobre os Direitos das Pessoas com Deficiência, aprovada no Brasil pelo Decreto Legislativo 186/2008, promulgado pelo Decreto 6.949/ 2009. Com status de emenda constitucional, a Convenção assegurava o sistema educacional inclusivo em todos os níveis, assim garantindo que as pessoas com deficiência, de qualquer idade, não fossem excluídas do sistema educacional geral, em nenhum nível, sob alegação de deficiência, assim como que recebessem o apoio necessário, no âmbito desse mesmo sistema educacional geral, com vistas a facilitar sua efetiva educação.

Em 2015 foi publicada a Lei 13.146, conhecida como Estatuto da Pessoa com Deficiência, que da mesma forma garantia o direito à educação, inclusive ao Ensino Superior, das pessoas com deficiência, em igualdade de condições.

Diante do panorama estatístico que decorre das informações dos Censos da Educação Básica analisados e da evolução legislativa no Brasil acerca do direito à educação da pessoa com deficiência, pode-se concluir que, não obstante os graves problemas de inclusão ainda existentes, o aumento de pessoas com deficiência matriculadas em salas regulares de escolas comuns evidencia que os preceitos legais nesta área estão gradativamente sendo postos em prática.

\section{REFERÊNCIAS}

BADR, Eid. Curso de direito educacional: o ensino superior brasileiro. Curitiba: Editora CRV, 2011.

BASTOS, Maria Helena Câmara. A instrução pública e o ensino mútuo no Brasil: uma história pouco conhecida (1808-1827). História da Educação, Pelotas: ASPHE; FaE; UFPel, (1), p. 115-133, abr. 1997.

BOBBIO, Norberto. A era dos direitos. 11. ed. Rio de Janeiro: Campus, 1992. 
BORGES, A. et al. A contribuição dos testes e provas piloto conjuntas para o censo 2010. In: ENCONTRO NACIONAL DE ESTUDOS POPULACIONAIS, 17., Caxambu, 2010. Disponível em: <http://www.abep.nepo.unicamp.br/ encontro2010/docs_pdf/tema_2/abep2010_2332.pdf>. Acesso em: 16 fev. 2016.

BRASIL. Cartilha do Censo 2010: pessoas com deficiência. Luiza Maria Borges Oliveira; Secretaria de Direitos Humanos da Presidência da República (SDH/ PR); Secretaria Nacional de Promoção dos Direitos da Pessoa com Deficiência (SNPD); Coordenação-Geral do Sistema de Informações sobre a Pessoa com Deficiência. Brasília: SDH-PR; SNPD, 2012.

. Constituição (1824). Constituição Política do Império do Brazil. Disponível em: <http://www.planalto.gov.br/ccivil_03/Constituicao/Constituicao24. htm>. Acesso em: 26 jun. 2015.

. Constituição (1891). Constituição da República dos Estados Unidos do Brasil. Disponível em: <http://www.planalto.gov.br/ccivil_03/Constituicao/ Constituicao91.htm>. Acesso em: 26 jun. 2015.

. Constituição (1934). Constituição da República dos Estados Unidos do Brasil. Disponível em: <http://www.planalto.gov.br/ccivil_03/Constituicao/ Constituicao34.htm>. Acesso em: 26 jun. 2015.

. Constituição (1937). Constituição dos Estados Unidos do Brasil. Disponível em: <http://www.planalto.gov.br/ccivil_03/Constituicao/Constituicao37.htm>. Acesso em: 26 jun. 2015.

. Constituição (1946). Constituição dos Estados Unidos do Brasil. Disponível em: <http://www.planalto.gov.br/ccivil_03/Constituicao/Constituicao46.htm>. Acesso em: 26 jun. 2015.

. Constituição (1967). Constituição da República Federativa do Brasil. Disponível em: <http://www.planalto.gov.br/ccivil_03/Constituicao/Constituicao67.htm>. Acesso em: 26 jun. 2015.

. Constituição (1988). Constituição da República Federativa do Brasil. Brasília, DF: Senado, 1988. 
BRASIL. Decreto $n^{\circ}$ 3.956, de 8 de outubro de 2001. 2001c. Disponível em: $<$ http://www.planalto.gov.br/ccivil_03/decreto/2001/d3956.htm>. Acesso em: 24 jun. 2015.

. Decreto $n^{0}$ 6.949, de 25 de agosto 2009. Promulga a Convenção Internacional sobre os Direitos das Pessoas com Deficiência e seu Protocolo Facultativo, assinados em Nova York, em 30 de março de 2007. Disponível em: $<$ http://www.planalto.gov.br/ccivil_03/_ato2007-2010/2009/decreto/d6949. htm>. Acesso em: 24 jun. 2015.

Decreto $n^{\circ}$ 7.611, de 17 de novembro 2011. Dispõe sobre a educação especial, o atendimento educacional especializado e dá outras providências. 2011a. Disponível em: <http://www.planalto.gov.br/ccivil_03/_ato20112014/2011/decreto/d7611.htm>. Acesso em: 26 jun. 2015.

. Lei $n^{\circ}$ 4.024, de 20 de dezembro de 1961. Fixa as Diretrizes e Bases da Educação Nacional. Disponível em: <http://www.planalto.gov.br/CCIVIL_03/ leis/L4024.htm>. Acesso em: 24 jun. 2015.

Lei $n^{0} 7.853$, de 24 de outubro de 1989. Dispõe sobre o apoio às pessoas portadoras de deficiência, sua integração social, sobre a Coordenadoria Nacional para Integração da Pessoa Portadora de Deficiência - Corde, institui a tutela jurisdicional de interesses coletivos ou difusos dessas pessoas, disciplina a atuação do Ministério Público, define crimes, e dá outras providências. Disponível em: <http://www.planalto.gov.br/ccivil_03/LeIs/L7853.htm>. Acesso em: 24 jun. 2015.

Lei $n^{\circ}$ 8.060, de 13 de julho de 1990. Dispõe sobre o Estatuto da Criança e do Adolescente e dá outras providências. Disponível em: $<\mathrm{http}: / /$ www.planalto.gov.br/CCIVIL_03/leis/L8069.htm>. Acesso em: 24 jun. 2015.

. Lei $n^{\circ}$ 9.394, de 20 de dezembro de 1996. Estabelece as diretrizes e bases da educação nacional. Disponível em: <http://www.planalto.gov.br/ CCIVIL_03/leis/L9394.htm>. Acesso em: 24 jun. 2015.

. Lei $n^{\circ}$ 13.146, de 06 de julho de 2015. Institui a Lei Brasileira de Inclusão da Pessoa com Deficiência (Estatuto da Pessoa com Deficiência). Disponível em: <http://www.planalto.gov.br/ccivil_03/_Ato2015-2018/2015/ Lei/L13146.htm>. Acesso em: 26 jan. 2016. 
BRASIL. Ministério da Educação. Resolução CNE/CEB 2, de 11 de setembro de 2011. Diário Oficial da União, Brasília, 14 set. 2011b. Seção 1E, p. 39-40. . Ministério da Educação. Diretrizes nacionais para a educação especial na educação básica. Secretaria de educação especial; MEC; SEESP, 2001a. . Conselho Nacional de Educação. Câmara de Educação Básica. Resolução CNE/CEB 2/2001. Diário Oficial da União, Brasília, Seção 1E, p. 39-40, 14 de setembro de $2001 b$.

BUENO, J. G. Silveira. Educação especial brasileira: integração/segregação do aluno diferente. São Paulo: Educ, 1993.

CARTOLANO, Maria Teresa Penteado. Benjamin Constant e a instrução pública no início da República. 1994. Tese (Doutorado) - Unicamp, Campinas, 1994.

COMPARATO, Fábio Konder. A afirmação histórica dos direitos humanos. São Paulo: Saraiva, 1999.

CURY, Carlos Roberto Jamil. Cidadania republicana e educação: governo provisório do Mal. Deodoro e Congresso Constituinte de 1890-1891. Rio de Janeiro: DP\&A Editora, 2001.

GARCIA, Rosalba Maria Cardoso. Educação inclusiva: reflexões a partir das políticas educacionais recentes. Contrapontos, Itajaí, vol. 5, n. 3, p. 343-351, set./dez. 2005.

FÁVERO, Eugênia Augusta Gonzaga. Direito das pessoas com deficiência: garantia de igualdade na diversidade. Rio de Janeiro: WVA, 2004.

IGLESIAS, Francisco de Assis. Constituintes e constituições brasileiras. São Paulo: Brasiliense, 1985.

INSTITUTO BRASILEIRO DE GEOGRAFIA E ESTATÍSTICA. IBGE. Censo demográfico - 2000: primeiros resultados da amostra. Disponível em: $<\mathrm{http}: / /$ www.ibge.gov.br/home/estatistica/populacao/censo2000/primeiros_resultados_amostra/tabela_brasil.shtm>. Acesso em: 16 fev. 2016. 
INSTITUTO BRASILEIRO DE GEOGRAFIA E ESTATÍSTICA. IBGE. Censo demográfico 2010: características gerais da população, religião e pessoas com deficiência. Disponível em: <http://www.ibge.gov.br/home/estatistica/populacao/censo2010/caracteristicas_religiao_deficiencia/caracteristicas_religiao_ deficiencia_tab_xls.shtm>. Acesso em: 16 fev. 2016.

Sinteses históricas: históricos dos censos. Censos demográficos. Disponível em: <http://memoria.ibge.gov.br/sinteses-historicas/historicos-dos-censos/censos-demograficos.html>. Acesso em: 25 jan. 2016.

INSTITUTO NACIONAL DE ESTUDOS E PESQUISAS EDUCACIONAIS ANÍSIO TEIXEIRA. Inep Censo escolar. Disponível em: <http://portal.inep. gov.br/basica-censo>. Acesso em: 26 jan. 2016a.

. Sinopses estatísticas da educação básica. Disponível em: <http://portal. inep.gov.br/basica-censo-escolar-sinopse-sinopse>. Acesso em: 16 fev. 2016b. LENZI, Maíra Bonna. Os dados sobre deficiência nos censos demográficos brasileiros. Trabalho apresentado no XVIII Encontro Nacional de Estudos Populacionais, Abep, realizado em Águas de Lindoia/SP - Brasil, de 19 a 23 de novembro de 2012. Disponível em: <www.abep.nepo.unicamp.br/xviii/anais/ files/ST35[845]ABEP2012.pdf> Acesso em: 26 jan. 2016.

MAZZOTTA, Marcos Jose Silveira. Educação especial no Brasil: história e políticas públicas. 6. ed. São Paulo: Cortez, 2011.

MEZZARI, Vilma Apda de Souza. A trajetória pedagógica de Benjamin Constant. 2001. Dissertação (Mestrado) - UEM, 2001.

MONTEIRO, Agostinho dos Reis. O direito à educação. Lisboa: Ed. Livros Horizonte, 1999.

OLIVEIRA, Romualdo Portela de. Educação e cidadania: o direito à educação na Constituição de 1988 da República Federativa do Brasil. 1995, p. 68. Tese (Doutorado) - Faculdade de Educação da Universidade de São Paulo, 1995.

ORGANIZAÇÃO DAS NAÇÕES UNIDAS. ONU. Concluding Observations on the initial report of Brazil. Realizado pelo Comitê sobre os Direitos das Pessoas com Deficiência (CRPD) na sessão de 17 de agosto a 4 de setembro de 2015. Disponível em: <http://tbinternet.ohchr.org/_layouts/treatybodyexternal/ Download.aspx?symbolno=CRPD $\% 2 \mathrm{fC} \% 2 \mathrm{fBRA} \% 2 \mathrm{fCO} \% 2 \mathrm{f} 1 \& \mathrm{Lang}=\mathrm{en}>$ Acesso em: 22 jan 2016. 
ORGANIZAÇÃO DAS NAÇÕES UNIDAS. ONU. Declaração universal dos direitos humanos. 1948. Disponível em: <www.direitoshumanos.usp.br>. Acesso em: 23 jun. 2015.

NAÇÕES UNIDAS NO BRASIL. ONUBR. Comitê da ONU sobre direitos das pessoas com deficiência divulga observações sobre o Brasil. Publicado em 11 setembro 2015. Disponível em: <https://nacoesunidas.org/comite-da-onu-sobre-os-direitos-das-pessoas-com-deficiencia-divulga-observacoes-finais-sobre-brasil/>. Acesso em: 22 jan. 2016.

. Convenção da ONU sobre direitos das pessoas com deficiência chega ao marco de 150 países. Publicado em 15 setembro 2014. Disponível em: <https:// nacoesunidas.org/convencao-da-onu-sobre-direitos-das-pessoas-com-deficiencia-chega-ao-marco-de-150-paises/>. Acesso em: 20 jan. 2016.

SILVA, Otto Marques da. A Epopéia ignorada: a pessoa deficiente na história do mundo de ontem e de hoje. São Paulo: Cedas, 1986.

ORGANIZAÇÃO DAS NAÇÕES UNIDAS PARA A EDUCAÇÃO, A CIÊNCIA E A CULTURA. Unesco. Declaração mundial sobre educação para todos. 1990. Disponível em: <http://unesdoc.unesco.org/images/0008/000862/086291por. pdf $>$. Acesso em: 24 jun. 2015.

. Declaração de Salamanca sobre princípios, política e prática em educação especial. 1994. Disponível em: <http://portal.mec.gov.br/seesp/arquivos/ pdf/salamanca.pdf>. Acesso em: 23 jun. 2015.

UNITED NATIONS. Committee on the Rights of Persons with Disabilities (CRPD). Concluding observations on the initial report of Brazil, 2015. Disponível em: <http://www.refworld.org/docid/55eed4d84.html>. Acesso em: $1^{\circ}$ out. 2016.

VIEIRA, Sofia Lerche. História da educação no Ceará: sobre promessas, fatos e feitos. Fortaleza: Edições Demócrito Rocha, 2002.

- A educação nas constituições: Brasil e Ceará. Fortaleza: Importec, 2007.

Recebido em: 2/10/2016

Aceito em: 18/10/2016 